\title{
Precisely Traceable Drug Delivery of Azoreductase-Responsive Prodrug for Colon Targeting via Multimodal Imaging
}

\author{
Xiao-bo Zhao, ${ }^{1,2 \ddagger}$ Wei Ha, ${ }^{1}$ Kun Gao, ${ }^{3}$ Yan-ping Shi ${ }^{1 *}$ \\ ${ }^{1}$ CAS Key Laboratory of Chemistry of Northwestern Plant Resources, Lanzhou Institute of Chemical \\ Physics, Chinese Academy of Sciences (CAS), Lanzhou 730000, People's Republic of China. Email: \\ shiyp@licp.cas.cn \\ ${ }^{2}$ University of Chinese Academy of Sciences, Beijing 100049, People's Republic of China \\ ${ }^{3}$ College of Chemistry and Chemical Engineering, Lanzhou University, Lanzhou 730000, People's \\ Republic of China
}

\section{Table of Contents}

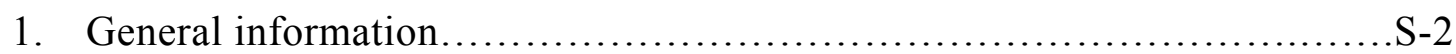

2. Chemical synthesis and characterization of prodrug AP-N=N-Cy ...........S-3

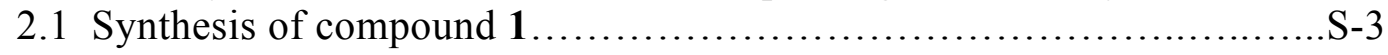

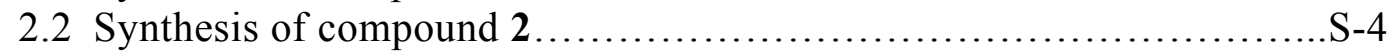

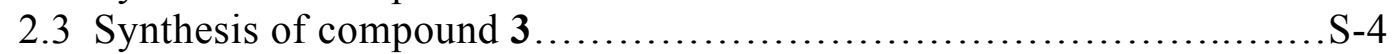

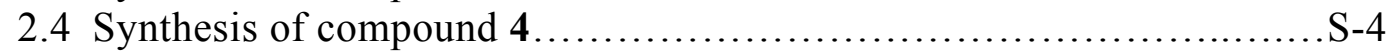

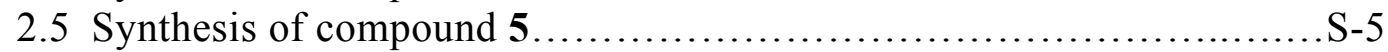

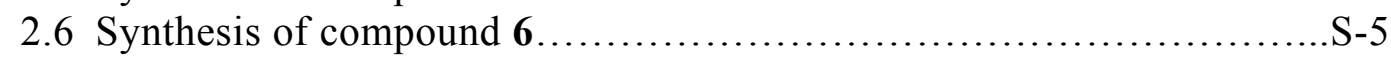

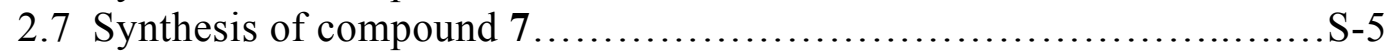

2.8 Synthesis of compound IR........................................ 6

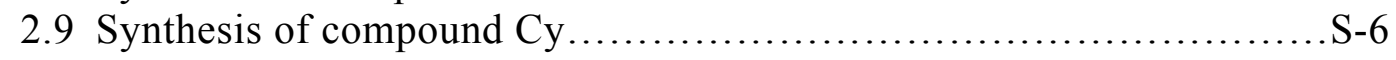

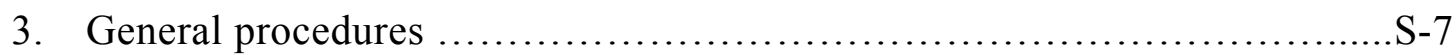

3.1 UV-vis and fluorescence spectra methods........................... -7

3.2 Determination of the selectivity toward azoreductases................ -7

3.3 Preparation of rat cecal contents ................................

3.4 Cell culture and in vitro cytotoxicity assays...........................

3.5 Fluorescence imaging and colocalization study of cells.....................S-8

3.6 UPLC and MS/MS conditions......................................... 8

3.7 Animals..........................................................

3.8 Fluorescence imaging of AP-N=N-Cy in vivolex vivo................. -9

3.9 Imaging mass spectra analysis.................................

3.10 Stability of prodrugs AP-N=N-Cy before reaching colon............S-10

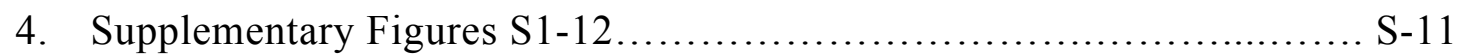

5. NMR and HRMS Spectra (Figures S13-33) ............................. 16

6. HPLC traces of prodrug AP-N=N-Cy and some important synthetic intermediates.......................................................

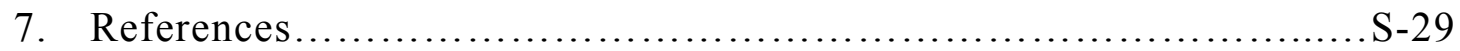




\section{General information}

4'-Demethylepipodophyllotoxin was obtained from Nanjing Spring \& Autumn Biological Engineering Co., Ltd (Nanjing, China). Methyl 4-aminobenzoate, 2, 3, 3-trimethylindolenine and iodomethane were purchased from HEOWNS Biochem Technologies LLC, (Tianjin, China). Sodium dithionite and cyclohexanone were supplied by Sinopharm Chemical Reagent Co., Ltd. The oxone was purchased from Shanghai Macklin Biochemical Co., Ltd. $\alpha$-Cyano-4-hydroxycinnamic acid ( $\alpha$-CHCA, 99\%) was purchased from Sigma-Aldrich Co., Ltd. Mito-Tracker Green was purchased from Beyotime Institute of Biotechnology (Shanghai, China). All other chemicals were purchased from qualified reagent supplies with analytical reagent grade and used without further purification.

The ${ }^{1} \mathrm{H}$ and ${ }^{13} \mathrm{C}$ NMR spectra were measured on a Bruker AVANCE III-400 spectrometer, and the chemical shifts of ${ }^{1} \mathrm{H}$ NMR are expressed in parts per million downfield relative to the internal tetramethylsilane $(\delta=0 \mathrm{ppm})$. High-resolution electrospray ionization mass spectrometry (HR-ESIMS) was measured on a Bruker microTOF-Q II mass spectrometer (Bruker Daltonics, Billerica, MA). The UV-vis absorption spectra were measured by UV-vis spectrophotometer (Perkin Elmer, Waltham, USA) with a $1 \mathrm{~cm}$-path-length quartz cuvette. The fluorescence spectra were acquired on a fluorescence spectrophotometer (Fluoromax-4, HORIBA, USA). The in vitro drug and fluorophore release were investigated by an ultra-high performance liquid chromatography mass spectrometry (UPLC-MS/MS) (Waters ACQUITY UPLC MS/MS, USA). Fluorescence images on cells were obtained on an Olympus Fluoview 1000 confocal laser scanning microscope (Olympus, Tokyo, Japan). Whole-body in vivo fluorescence images were obtained using an IVIS Lumina Series III imaging system (PerkinElmer, USA). Ex vivo fluorescence images of different organs of mice were obtained using VISQUETM In Vivo Elite Preclinical Optical Imaging System (Viewworkd Co., Ltd. Korea). Imaging mass spectra were acquired on an iMScope TRIO (Shimadzu, Kyoto, Japan). The purity of prodrug $\mathrm{AP}-\mathrm{N}=\mathrm{N}-\mathrm{Cy}$ and other key compounds were determined by high performance liquid chromatography (HPLC) on a Waters 1525 HPLC system installed with a C18 column (BDS HYPERSIL, $5 \mu \mathrm{m}, 250 \mathrm{~mm} \times 4.6 \mathrm{~mm}$ ) and a photodiode array detector. HPLC results showed that the purity of all tested compounds were $>95 \%$. 


\section{Chemical synthesis and characterization of prodrug AP-N=N-Cy (Scheme S1)}

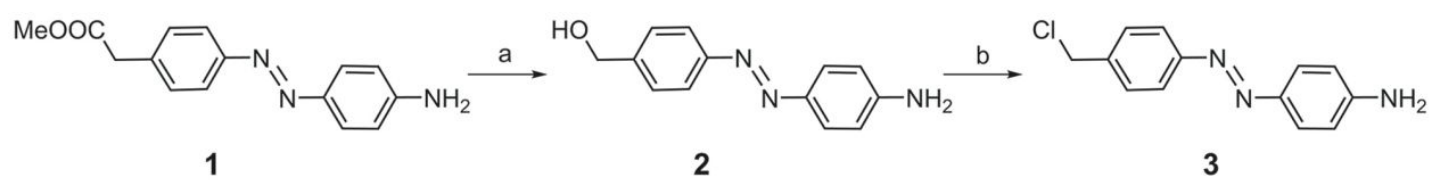

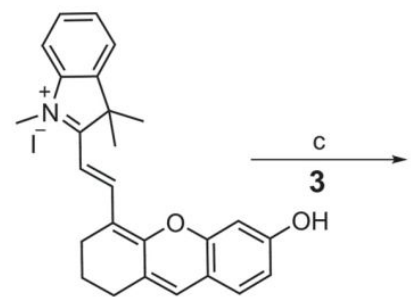

Cy

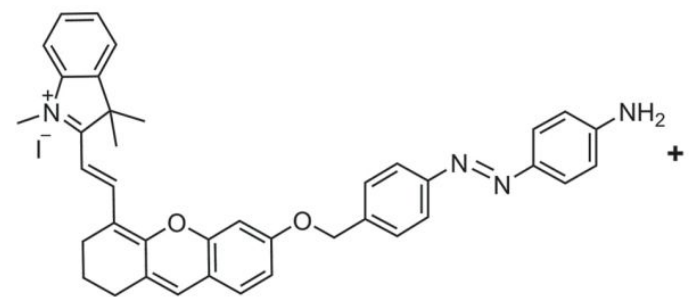

5

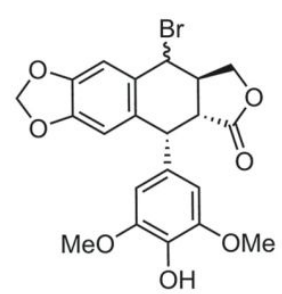

6

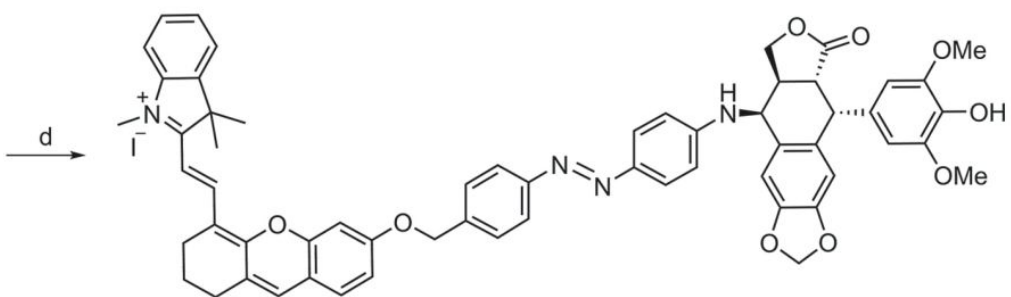

AP-N=N-Cy

Scheme S1. Synthesis of prodrug AP-N=N-Cy: (a) $\mathrm{LiAlH}_{4}, \mathrm{CH}_{2} \mathrm{Cl}_{2}$, THF, $25{ }^{\circ} \mathrm{C}, 4 \mathrm{~h}, 92 \%$; (b) $\mathrm{SOCl}_{2}, \mathrm{Et}_{3} \mathrm{~N}, \mathrm{CH}_{2} \mathrm{Cl}_{2}, 25^{\circ} \mathrm{C}, 4 \mathrm{~h}, 82 \%$; (c) $\mathrm{K}_{2} \mathrm{CO}_{3}, \mathrm{CH}_{3} \mathrm{CN}$, reflux, $4 \mathrm{~h}, 45 \%$; (d) $\mathrm{K}_{2} \mathrm{CO}_{3}$, $\mathrm{CH}_{3} \mathrm{CN}$, reflux, $4 \mathrm{~h}, 38 \%$.

\subsection{Synthesis of compound 1}

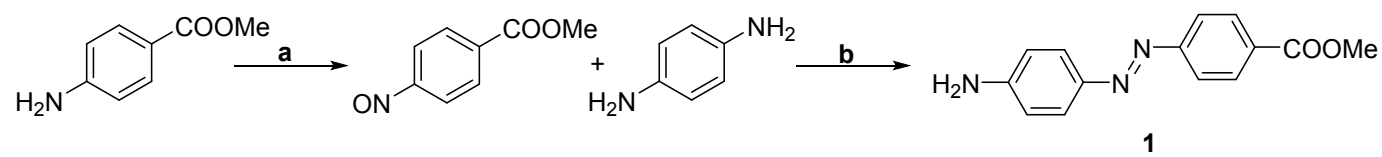

Scheme S2. Synthesis of compound 1: (a) Oxone, $\mathrm{CH}_{2} \mathrm{Cl}_{2}, \mathrm{H}_{2} \mathrm{O}, 25{ }^{\circ} \mathrm{C}, 5 \mathrm{~h}$; (b) $\mathrm{CH}_{3} \mathrm{COOH}$, $\mathrm{CH}_{2} \mathrm{Cl}_{2}$, THF, $25^{\circ} \mathrm{C}, 16 \mathrm{~h}$.

Compound 1 was synthesized according to the previously reported methods (Scheme S2). ${ }^{1,2}$ Firstly, a solution of oxone $(9.7 \mathrm{~g}, 16 \mathrm{mmol})$ in water $(50 \mathrm{~mL})$ was added to a solution of methyl 4-aminobenzoate (1.5 g, $10 \mathrm{mmol})$ in $\mathrm{CH}_{2} \mathrm{Cl}_{2}(20 \mathrm{~mL})$. The biphasic mixture was stirred vigorously at room temperature for $5 \mathrm{~h}$ until the organic phase turns dark green. The organic phase was separated and washed with 0.1 $\mathrm{N} \mathrm{HCl}(3 \times 15 \mathrm{~mL})$. The organic phase was then dried over $\mathrm{MgSO}_{4}$ and removed the solvent to provide the 4-nitrosobenzoic acid methyl ester as a yellow power. Subsequently, the crude 4-nitrosobenzoic acid methyl ester was dissolved in $\mathrm{CH}_{2} \mathrm{Cl}_{2}$ $(15 \mathrm{~mL})$ and dry THF $(5 \mathrm{~mL})$, followed by addition of $p$-phenylenediamine $(1.1 \mathrm{~g}, 10$ $\mathrm{mmol})$ and acetic acid $(2.84 \mathrm{~mL}, 50 \mathrm{mmol})$. The reaction mixture was allowed to stir 
at room temperature for $16 \mathrm{~h}$ and the solvent was removed under reduced pressure, the crude product was purified by column chromatography $\left(\mathrm{CH}_{2} \mathrm{Cl}_{2}\right)$ to provide compound 1 as a yellow solid. ${ }^{1} \mathrm{H}$ NMR (400 MHz, $\left.\mathrm{CDCl}_{3}\right): \delta 8.15$ (d, $\left.J=8.8 \mathrm{~Hz}, 2 \mathrm{H}\right)$, 7.83-7.88 (dd, $\left.J_{I}=8.4 \mathrm{~Hz}, J_{2}=12.0 \mathrm{~Hz}, 4 \mathrm{H}\right), 6.74(\mathrm{~d}, J=8.8 \mathrm{~Hz}, 2 \mathrm{H}), 4.15$ (brs, $2 \mathrm{H}$ ), $3.94(\mathrm{~s}, 3 \mathrm{H}) .{ }^{13} \mathrm{C} \mathrm{NMR}\left(100 \mathrm{MHz}, \mathrm{CDCl}_{3}\right): \delta 116.8,155.7,150.3,145.6,130.6,130.5$, 125.6, 122.1, 114.6, 52.2. HRMS calcd for $\mathrm{C}_{14} \mathrm{H}_{13} \mathrm{~N}_{3} \mathrm{O}_{2} \mathrm{Na}$ : 278.0900 [M+Na $]^{+}$; found, $278.0888[\mathrm{M}+\mathrm{Na}]^{+}$.

\subsection{Synthesis of compound 2}

A solution of compound $1(269 \mathrm{mg}, 1 \mathrm{mmol})$ in dry $\mathrm{CH}_{2} \mathrm{Cl}_{2}(10 \mathrm{~mL})$ was cooled to $0{ }^{\circ} \mathrm{C}$, lithium aluminium hydride $(40 \mathrm{mg}, 1 \mathrm{mmol})$ in $5 \mathrm{~mL}$ of dry $\mathrm{THF}$ was added. The reaction mixture was stirred at room temperature for $4 \mathrm{~h}$. After that, the reaction was quenched by adding $2 \mathrm{~mL}$ water dropwise. The solution was washed with saturated sodium bicarbonate solution $(5 \mathrm{~mL} \times 3)$, and dried with $\mathrm{Na}_{2} \mathrm{SO}_{4}$. The solvent was evaporated to dryness to provide crude product. The crude product was further purified by column chromatography using $\mathrm{CH}_{2} \mathrm{Cl}_{2} / \mathrm{MeOH}(80: 1$, v/v) to provide compound 2 as a yellow solid $210 \mathrm{mg}$ (yield 92\%). ${ }^{1} \mathrm{H}$ NMR (400 $\mathrm{MHz}, \mathrm{CDCl}_{3}$ ): $\delta$ 7.78-7.85 (m, 4H), 7.47 (d, J=8.0 Hz, 2H), 6.74 (d, $J=8.4 \mathrm{~Hz}, 2 \mathrm{H}), 4.76$ (d, J=5.6 Hz, 2H), 4.05 (s, 2H). $\left.{ }^{13} \mathrm{C} \mathrm{NMR} \mathrm{(100} \mathrm{MHz,} \mathrm{CDCl}_{3}\right): \delta 157.9,156.6,149.3,148.0,132.3$, 130.2, 126.8, 118.6, 67.8. HRMS calcd for $\mathrm{C}_{13} \mathrm{H}_{14} \mathrm{~N}_{3} \mathrm{O}: 228.1131[\mathrm{M}+\mathrm{H}]^{+}$; found, $228.1135[\mathrm{M}+\mathrm{H}]^{+}$. HPLC: $t \mathrm{R}=3.95 \min (95.3 \%$ purity).

\subsection{Synthesis of compound 3}

Compound $\mathbf{3}$ was synthesized by chlorinated compound $\mathbf{2}$ with thionyl chloride. The detailed synthesis procedures for new compound $\mathbf{3}$ were presented in the article.

\subsection{Synthesis of compound 4}

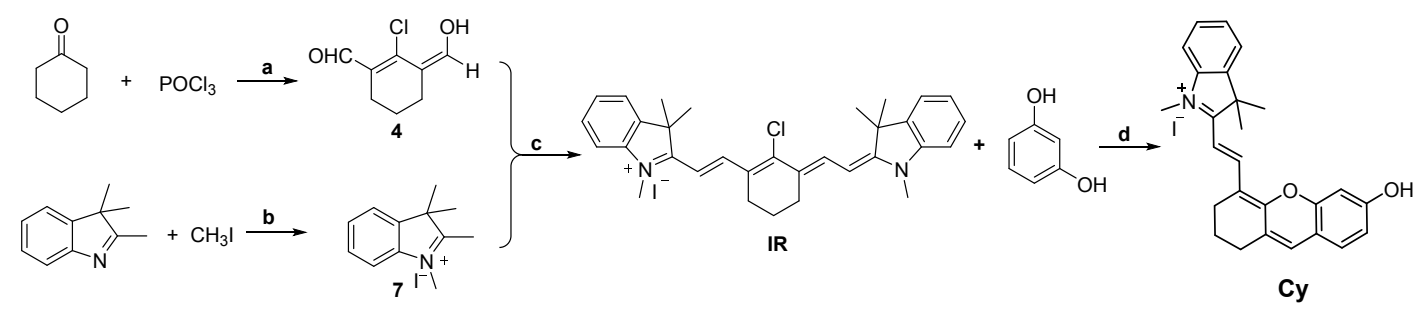

Scheme S3. Synthesis of compound Cy: (a) $\mathrm{CH}_{2} \mathrm{Cl}_{2}$, DMF, $4 \mathrm{~h}$, reflux; (b) $\mathrm{MeCN}, 65^{\circ} \mathrm{C}$, $4 \mathrm{~h}$; (c) $\mathrm{CH}_{3} \mathrm{COONa}$, acetic anhydride, $70^{\circ} \mathrm{C}, 2 \mathrm{~h}$; (d) $\mathrm{MeCN}, \mathrm{K}_{2} \mathrm{CO}_{3}, 60^{\circ} \mathrm{C}$, $4 \mathrm{~h}$.

Compound 4 was synthesized according to the previously reported methods 
(Scheme S3). ${ }^{3}$ A solution of $\mathrm{POCl}_{3}(1.85 \mathrm{~mL}, 20 \mathrm{mmol})$ in $\mathrm{CH}_{2} \mathrm{Cl}_{2}(5 \mathrm{~mL})$ was added dropwise to a solution of dimethylformamide (DMF, $2 \mathrm{~mL}, 26 \mathrm{mmol}$ ) and cyclohexanone $(0.5 \mathrm{~g}, 5 \mathrm{mmol})$ in $\mathrm{CH}_{2} \mathrm{Cl}_{2}(10 \mathrm{~mL})$ at $0{ }^{\circ} \mathrm{C}$. The reaction mixture was stirred at $0{ }^{\circ} \mathrm{C}$ for $30 \mathrm{~min}$, and then refluxed for $4 \mathrm{~h}$. The solution was cooled and poured into $200 \mathrm{~mL}$ ice water and a large amount of precipitation was obtained by filtrated. The precipitation was dried to afford crude compound 4 without further purification.

\subsection{Synthesis of compound 5}

Compound $\mathbf{5}$ was synthesized by reacted compound $\mathbf{3}$ with compound Cy in the presence of $\mathrm{K}_{2} \mathrm{CO}_{3}$. The detailed synthesis procedures for new compound $\mathbf{5}$ were presented in the article.

\subsection{Synthesis of compound 6}

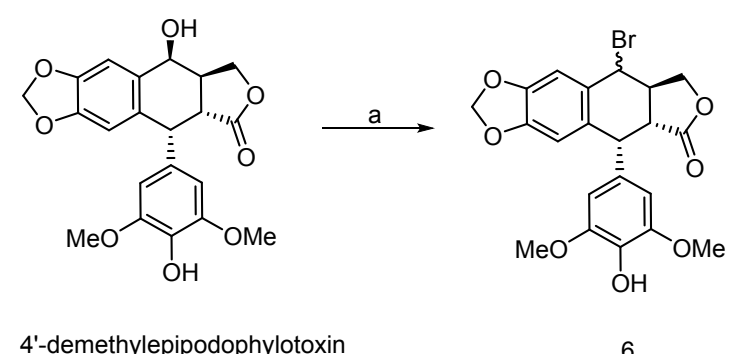

Scheme S4. Synthesis of compound 6: (a) $\mathrm{HBr}(\mathrm{g}), \mathrm{CH}_{2} \mathrm{Cl}_{2}, 0{ }^{\circ} \mathrm{C}, 2 \mathrm{~h}$.

Compound 6 was synthesized according to the previously reported methods (Scheme S4). ${ }^{5}$ A solution of 4'-demethylepipodophylotoxin (4 g, $1 \mathrm{mmol}$ ) in $50 \mathrm{~mL}$ of dry $\mathrm{CH}_{2} \mathrm{Cl}_{2}$ was bubbled with dry hydrogen bromide gas at $0{ }^{\circ} \mathrm{C}$ for $2 \mathrm{~h}$. After that, nitrogen was bubbled to the solution for $20 \mathrm{~min}$. The solution was then evaporated to dryness to provide crude compound 6 without further purification.

\subsection{Synthesis of compound 7}

Compound 7 was synthesized according to the previously reported methods (Scheme S3). ${ }^{4}$ A solution of 2, 3, 3-trimethylindolenine (1.59 g, $\left.10 \mathrm{mmol}\right)$ and iodomethane $(2.13 \mathrm{~g}, 15 \mathrm{mmol})$ in $\mathrm{CH}_{3} \mathrm{CN}(10 \mathrm{~mL})$ was refluxed at $65^{\circ} \mathrm{C}$ for $4 \mathrm{~h}$. The solution was cooled and filtrated. The resulting residue was dry overnight to obtain the compound 7 . 


\subsection{Synthesis of compound IR}

Compound IR was synthesized according to the previously reported methods (Scheme S3). ${ }^{4}$ A mixture of compound $4(520 \mathrm{mg}, 3.0 \mathrm{mmol})$, sodium acetate trihydrate $(816 \mathrm{mg}, 6.0 \mathrm{mmol})$ and compound $7(1.8 \mathrm{~g}, 6.0 \mathrm{mmol})$ in acetic anhydride $(20 \mathrm{~mL})$ was heated at $70{ }^{\circ} \mathrm{C}$ for $2 \mathrm{~h}$ under an nitrogen atmosphere. After that, the reaction mixture was cooled and a large amount of green precipitation was collected by filtrated. The crude precipitation was further purified by column chromatography using $\mathrm{CH}_{2} \mathrm{Cl}_{2} / \mathrm{MeOH}(20: 1, \mathrm{v} / \mathrm{v})$ to provide compound IR as a dark green solid. ${ }^{1} \mathrm{H}$ NMR (400 MHz, DMSO-d6): $\delta 8.23$ (d, $J=14.0 \mathrm{~Hz}, 2 \mathrm{H}), 7.63$ (d, $J=7.2 \mathrm{~Hz}, 2 \mathrm{H}$ ), 7.40-7.44 (m, 4H), 7.26-7.29 (m, 2H), $6.30(\mathrm{~d}, J=14.0 \mathrm{~Hz}, 2 \mathrm{H}), 3.69(\mathrm{~s}, 6 \mathrm{H})$, 2.70-2.72 (m, 4H), 1.83-1.86 (m, 2H), 1.66 (s, 12H). ${ }^{13} \mathrm{C}$ NMR (100 MHz, DMSO-d6): $\delta 172.5,147.6,142.8,142.6,140.9,128.5,126.0,125.1,122.3,111.4,101.9,48.8$, 31.6, 27.3, 25.9, 20.4. HRMS calcd for $\mathrm{C}_{32} \mathrm{H}_{36} \mathrm{~N}_{2} \mathrm{Cl}$ : 483.2562 [M-I] $]^{+}$; found, $483.2539[\mathrm{M}-\mathrm{I}]^{+}$.

\subsection{Synthesis of compound $\mathrm{Cy}$}

Compound Cy was synthesized according to the previously reported methods (Scheme S3). ${ }^{4} \mathrm{~K}_{2} \mathrm{CO}_{3}(552 \mathrm{mg}, 4.0 \mathrm{mmol}$ ) was added to a solution of compound IR $(610 \mathrm{mg}, 1.0 \mathrm{mmol})$ and resorcinol $(220 \mathrm{mg}, 2.0 \mathrm{mmol})$ in dry $\mathrm{CH}_{3} \mathrm{CN}(5 \mathrm{~mL})$. The mixture was stirred at $60{ }^{\circ} \mathrm{C}$ for $4 \mathrm{~h}$ under nitrogen atmosphere. The solvent was evaporated and the crude product was purified by column chromatography using $\mathrm{CH}_{2} \mathrm{Cl}_{2} / \mathrm{MeOH}(40: 1, \mathrm{v} / \mathrm{v})$ to provide compound $\mathrm{Cy}$ as a dark blue solid. ${ }^{1} \mathrm{H}$ NMR (400 MHz, DMSO-d6): $\delta 8.26$ (d, $J=14.0 \mathrm{~Hz}, 1 \mathrm{H}), 7.58$ (d, $J=7.2 \mathrm{~Hz}, 1 \mathrm{H}), 7.552$ (s, 1H), 7.39-7.41 (m, 3H), 7.24 (t, $J=7.2 \mathrm{~Hz}, 2 \mathrm{H}), 6.66$ (d, $J=9.2 \mathrm{~Hz}, 1 \mathrm{H}), 6.57$ (s, 1H), 6.14 (d, $J=14.4 \mathrm{~Hz}, 1 \mathrm{H}), 3.64$ (s, 3H), 2.63-2.67 (m, 4H), 1.80-1.81 (m, 2H), 1.68 (s, $6 \mathrm{H}) .{ }^{13} \mathrm{C}$ NMR (100 MHz, DMSO $\left.d 6\right): \delta$ 159.6, 156.0, 143.0, 140.6, 138.3, 136.7, $129.6,128.4,124.5,122.2$, 121.2, 120.1, 115.0, 114.6, 110.9, 102.1, 99.8, 48.5, 38.9, 31.3, 27.8, 27.6, 23.8, 20.4. HRMS calcd for $\mathrm{C}_{26} \mathrm{H}_{26} \mathrm{NO}_{2}$ : 384.1958 [M-I] $]^{+}$; found, $384.1939[\mathrm{M}-\mathrm{I}]^{+}$. 


\section{General procedures}

\subsection{UV-vis and fluorescence spectra methods}

For the UV-vis absorption and fluorescence spectra of prodrug AP-N=N-Cy toward sodium dithionite and rat cecal contents, $10 \mu \mathrm{M}$ AP-N=N-Cy working solution in deoxygenated phosphate saline buffer (PBS, pH 7.4, $10 \mathrm{mM}, 1 \% \mathrm{DMSO}, 37{ }^{\circ} \mathrm{C}$ ) which prepared by bubbling nitrogen for 15 min was used. Various analytes were added to the working solution and the reactions were performed at $37^{\circ} \mathrm{C}$ for different time. The finally UV-vis absorption were measured in $\mathrm{CH}_{3} \mathrm{OH} / \mathrm{PBS}$ buffer $(\mathrm{v} / \mathrm{v}=1: 1,5$ $\mathrm{mM}, \mathrm{pH} 7.4$ ), while the fluorescence spectra were acquired at $\lambda_{\mathrm{ex} / \mathrm{em}}=679 / 708 \mathrm{~nm}$ in $\mathrm{CH}_{3} \mathrm{OH} / \mathrm{PBS}$ buffer (v/v=1:1, $5 \mathrm{mM}$, pH 7.4). For comparison, the solution containing neither sodium dithionite nor rat cecal contents (control) was measured under the same conditions at the same time.

\subsection{Determination of the selectivity toward azoreductases}

Prodrug AP-N=N-Cy $(10 \mu \mathrm{M})$ in deoxygenated PBS buffer $(\mathrm{pH}=7.4,10 \mathrm{mM}, 1 \%$ DMSO) was incubated with rat colon contents $(1 \mathrm{~mL})$, trypsin $(4.5 \mathrm{mg} / \mathrm{mL})$, amylase $(5.3 \mathrm{mg} / \mathrm{mL})$, lipase $(4.6 \mathrm{mg} / \mathrm{mL})$, cellulase $(1 \mathrm{~mL})$ and proteinase $\mathrm{K}$. $(1 \mathrm{~mL})$, respectively. The solutions were kept at $37^{\circ} \mathrm{C}$ for $12 \mathrm{~h}$. The fluorescence spectra were then measured at $\lambda_{\mathrm{ex} / \mathrm{em}}=679 / 708 \mathrm{~nm}$ in $\mathrm{CH}_{3} \mathrm{OH} / \mathrm{PBS}$ buffer $(\mathrm{v} / \mathrm{v}=1: 1,5 \mathrm{mM}, \mathrm{pH} 7.4)$.

\subsection{Preparation of rat cecal contents}

This experiment has been approved by the ethics committee. A deoxygenated solution of PBS buffer (10 mM, pH 7.4) was prepared by bubbling nitrogen for 15 min at $0{ }^{\circ} \mathrm{C}$. Male Sprague-Dawley rats were sacrificed and the cecum was dissected in the absence of oxygen. The cecal contents were immediately placed into the previously prepared deoxygenated PBS buffer to make a $10 \% \mathrm{w} / \mathrm{v}$ suspension with bubbling nitrogen for $10 \mathrm{~min}$. The solution was centrifuged at $4000 \mathrm{rpm} / \mathrm{min}$ for 10 min to remove debris. The centrifuged solution was directly use to the next experiments.

\subsection{Cell culture and in vitro cytotoxicity assays}

Hep G2, HeLa and HCT 116 cells were cultured according to the reported method. ${ }^{6}$ For the in vitro cytotoxicity assays, AdP and AP-N=N-Cy stock solutions were prepared at $100 \mathrm{mM}$ in DMSO and diluted with culture medium to the final concentration. Different cell lines were incubated with $0,6.75,12.50,25.00$ and 50.00 
$\mu \mathrm{M}$ of test compounds for $24 \mathrm{~h}$ at $37^{\circ} \mathrm{C}$. The cell viability of were determined by a MTT assay according to the reported procedures. ${ }^{6}$ The viability of the cells without test compounds was set to represent $100 \%$ of viability (control) and the results were expressed as percentage of these control. Each assay was performed in quintuplicate.

\subsection{Fluorescence imaging and colocalization study of cells}

For fluorescence microscopy, the Hep G2 and HeLa cells were seeded on a glass-bottom culture dishes and cultured in the culture medium for $24 \mathrm{~h}$, prodrug AP-N=N-Cy $(10 \mu \mathrm{M})$ and Mito-Tracker Green (commercial mitochondria tracker, 1 $\mu \mathrm{M})$ were added to the dishes and incubated at $37^{\circ} \mathrm{C}$ for $2 \mathrm{~h}$. The medium was then removed and the dishes were washed with PBS buffer three times. After adding fresh medium, fluorescence images were obtained by confocal laser scanning microscopy from green channels (excitation wavelength at $488 \mathrm{~nm}$, and the emission wavelength from $500 \mathrm{~nm}$ to $600 \mathrm{~nm}$ ) and NIR channels (excitation wavelength at $633 \mathrm{~nm}$, and the emission wavelength from $650 \mathrm{~nm}$ to $750 \mathrm{~nm}$ ).

\subsection{UPLC and MS/MS conditions}

The UPLC experiments were carried out on a Waters ACQUITY UPLC system. In a typical experiment, upon incubation of $10 \mu \mathrm{M}$ AP-N $=\mathrm{N}-\mathrm{Cy}$ with rat colon contents in deoxygenated PBS buffer $\left(\mathrm{pH}=7.4,10 \mathrm{mM}, 1 \%\right.$ DMSO, $\left.37{ }^{\circ} \mathrm{C}\right)$, the release of Cy and AdP were qualitatively and quantitatively determined by ultra performance liquid chromatography mass spectrometry.

The separation of Cy and AdP were achieved on a UPLC C18 column $(2.1 \times 50$ $\mathrm{mm}, 1.8 \mu \mathrm{m})$. The gradient elution was used with $\mathrm{A}$ (acetonitrile) and B (water, ammonium acetate, $5 \mathrm{mM}$ ) as mobile phase at a flow rate of $0.3 \mathrm{~mL} / \mathrm{min}: 0-1.5 \mathrm{~min}$, 98\% B; 1.5-2.5 min, 98-30\% B; 2.5-3.5 min, 30\% B; 3.5-4.0 min, 30-98\% B; 4.0-5.5 $\min , 98 \% \mathrm{~B}$. The column temperature was maintained at $35{ }^{\circ} \mathrm{C}$ and the injection volume was $1 \mu \mathrm{L}$ each time. The detection and identifications of AdP and Cy were performed on a Waters ACQUITY tandem triple quadrupole mass spectrometer (TQD) equipped with a Z-Spray multi-mode electrospray ionization/atmospheric pressure chemical ionization (ESI/APCI) ion source. The MS/MS analysis conditions were optimized as follows: source temperature, $110{ }^{\circ} \mathrm{C}$; desolvation temperature, $350{ }^{\circ} \mathrm{C}$; The flow rates of desolvation gas (nitrogen $99.999 \%$ ), $600 \mathrm{~L} / \mathrm{h}$; the flow rates of cone gas (argon 99.999\%), $50 \mathrm{~L} / \mathrm{h}$. The data acquisition and the system control were performed using a MassLynx 4.1 work station (Waters, USA). 


\subsection{Animals}

All animal experiments were approved by the Experimental Animal Use and Care Committee, Lanzhou University and in accordance with the principles of laboratory animal operation regulation. The Chinese Kunming mice (8-20 g) and Sprague-Dawley rats (200-210 g) were purchased from Lanzhou University.

\subsection{Fluorescence imaging of $\mathrm{AP}-\mathrm{N}=\mathrm{N}-\mathrm{Cy}$ in vivo/ex vivo}

Chinese Kun Ming mice were fasted for 12 hours and then gavaged with AP-N=N-Cy $(0.1 \mathrm{~mL}, 2 \mathrm{mg} / \mathrm{kg}, n=3)$. At different time points, 0 (immediately after gavage), 2, 4, 8, 12, 16, 20, 24 and $36 \mathrm{~h}$, the mice were anesthetized and the in vivo fluorescence imaging was performed $\left(\lambda_{\mathrm{ex}}=660 \mathrm{~nm}, \lambda_{\mathrm{em}}=710 \mathrm{~nm}\right)$. For the ex vivo fluorescence imaging, the Chinese Kun Ming mice were randomly divided into two groups (fed and fasted mice), each group contain 8 mice and maintained under standard condition. The fed mice were fed before gavage, while the fasted mice were fasted for 12 hours before gavage. At different time points, 0 (immediately after gavage), 4, 8, 12, 16, 20, 24 and $36 \mathrm{~h}$, two mice were taken from each group randomly. The mice were sacrificed immediately and the large intestine was dissected for subsequent ex vivo fluorescent imaging experiments. Meanwhile, the different organs, including the stomach, small intestine, cecum, colorectum, kidney, heart, lung, liver and spleen of the corresponding fasted mice taken out at 0 and $12 \mathrm{~h}$ were dissected for biodistribution investigation via ex vivo fluorescent imaging. The fluorescence images of ex vivo were acquired using a 630-680 nm excitation filter and a 690-740 nm emission filter.

\subsection{Imaging mass spectrometry analysis}

Fasted status group mice was sacrificed after gavage with $\mathrm{AP}-\mathrm{N}=\mathrm{N}-\mathrm{Cy}(0.1 \mathrm{~mL}$, $2 \mathrm{mg} / \mathrm{kg}$ ) for $12 \mathrm{~h}$, different organs, including the stomach, small intestine, cecum, colorectum, kidney, heart, lung, liver and spleen were dissected and frozen at $-80{ }^{\circ} \mathrm{C}$. As a control, colon tissues of fasted status group mice were also dissected after gavage with PBS $(0.1 \mathrm{~mL})$ at $12 \mathrm{~h}$. The frozen tissues were fixed on a holder and sliced at $15 \mu \mathrm{m}$ thickness with a cryomicrotome (Leica CM 1950, Germany) under $-20^{\circ} \mathrm{C}$. The tissue sections were placed on Indium-tin-oxide (ITO)-coated glass slides (100 $\Omega / \mathrm{m}^{2}$, Matsunami Glass, Osaka, Japan). The glass slides were dried and the matrix CHCA was deposited on the surface of tissue sections using an iMLayer (Shimadzu, Kyoto, Japan). 
Imaging mass spectra were analysis using an imaging mass spectrometer (iMScope TRIO Shimadzu, Kyoto, Japan). Data were collected at $40 \mu \mathrm{m}$ intervals. For each tissue pixel, the surface was laser-irradiated with 100 shots $(1000 \mathrm{~Hz}$ repetition rate, $10 \mu \mathrm{m}$ laser diameter, 35 laser intensity). The detector voltage of the microchannel plate detector was $1.95 \mathrm{kV}$, while the sample voltage was $3.5 \mathrm{kV}$. All the data were acquired in the positive-ion detection mode (m/z range of 150-500) and the MS/MS analysis was performed to confirm the Cy and AdP compound with selected precursor $m / z 369.17$ and 476.16, respectively.

\subsection{Stability of prodrugs AP-N=N-Cy}

In vitro digestion experiments were carried out at $37{ }^{\circ} \mathrm{C}$ to test the stability of prodrugs AP-N=N-Cy. Simulated saliva fluid, gastric fluid, duodenal fluid and colon fluid were prepared according to the reported method. ${ }^{7,8}$ The prodrug and simulated saliva fluid $(0.64 \mathrm{~mL})$ were incubated for $5 \mathrm{~min}$. Then, simulated gastric juice (1.26 $\mathrm{mL}$ ) was added, and the mixture was incubated for $2 \mathrm{~h}$. After that, bicarbonate solution $(1 \mathrm{M}, 0.10 \mathrm{~mL})$, simulated duodenal juice $(1.26 \mathrm{~mL})$ and bile $(0.64 \mathrm{~mL})$ were added and the mixture was incubated for another $2 \mathrm{~h}$. The mixture was centrifuged at given times from the beginning of the assay $(5,35,65,95,125,155,185,215,245$, $250,275,300$, and $315 \mathrm{~min}$ ), and then fluorescence spectra were acquired at $\lambda_{\text {ex/em }}=679 / 708 \mathrm{~nm}$ in $\mathrm{CH}_{3} \mathrm{OH} / \mathrm{PBS}$ buffer $(\mathrm{v} / \mathrm{v}=1: 1,5 \mathrm{mM})$, respectively. Each assay was performed in triplicate with duplicated samples. 


\section{Supplementary Figures S1-S12}

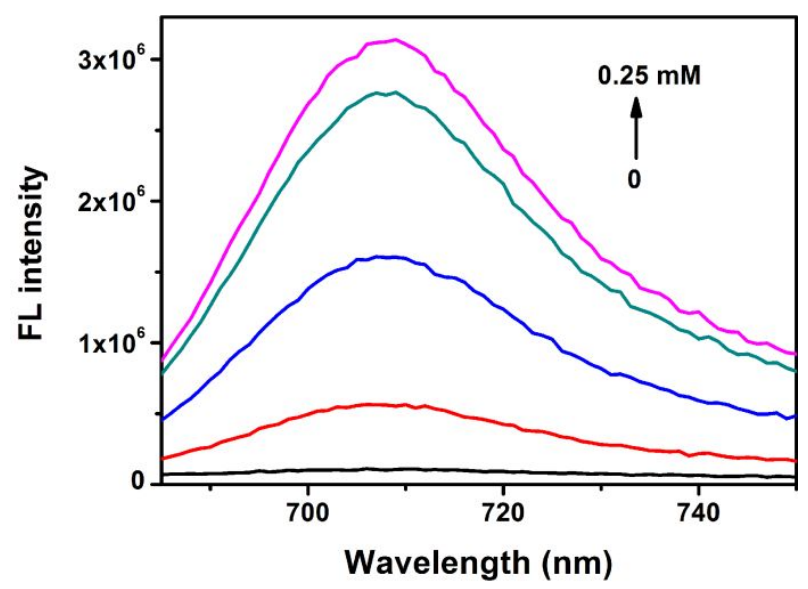

Figure S1. Fluorescence spectra of AP-N=N-Cy $(10 \mu \mathrm{M})$ after incubation with different amount of $\mathrm{Na}_{2} \mathrm{~S}_{2} \mathrm{O}_{4}(0,0.05,0.1,0.2$ and $0.25 \mathrm{mM})$ for $16 \mathrm{~min}$.

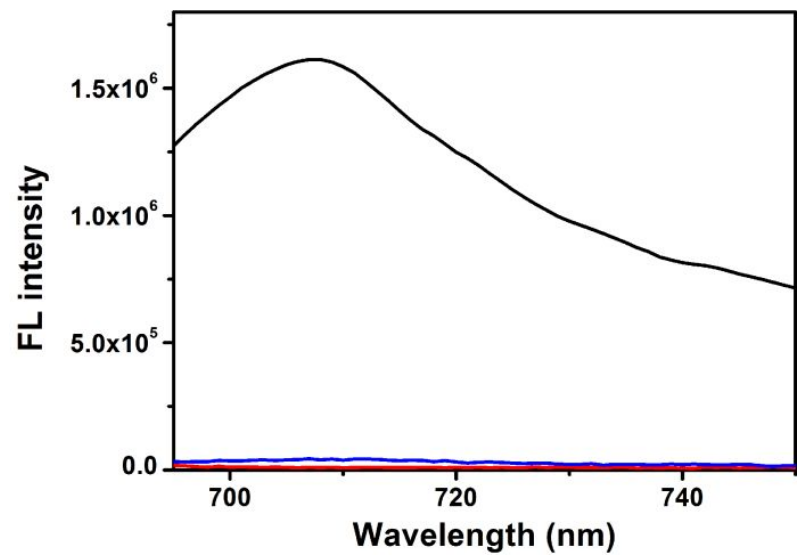

Figure S2. Fluorescence spectra of cecal contents (red), AP-N=N-Cy $(10 \mu \mathrm{M})$ incubation with $1 \mathrm{~mL}$ of cecal contents (black) and sterilized cecal contents (blue) for $12 \mathrm{~h}$.

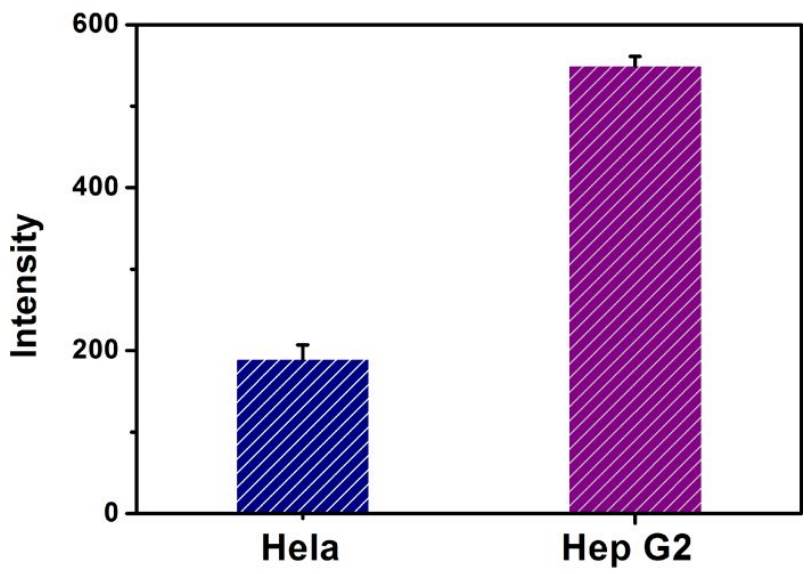

Figure S3. Relative fluorescence intensity of HeLa and Hep G2 cells after incubation with AP-N=N-Cy for $2 \mathrm{~h}$ with $\lambda_{\text {ex }}=633 \mathrm{~nm}, \lambda_{\text {em }}=650-750 \mathrm{~nm}$. 


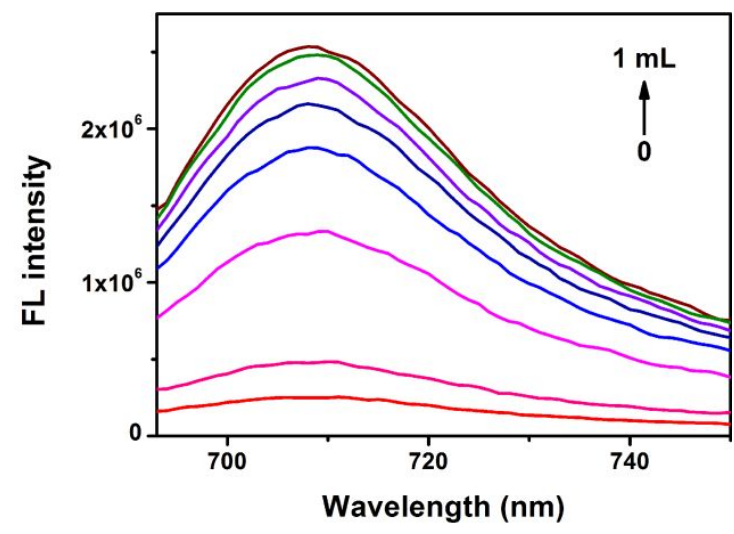

Figure S4. Fluorescence spectra of AP-N=N-Cy $(10 \mu \mathrm{M})$ after incubation with different volume of cecal contents for $12 \mathrm{~h}$.

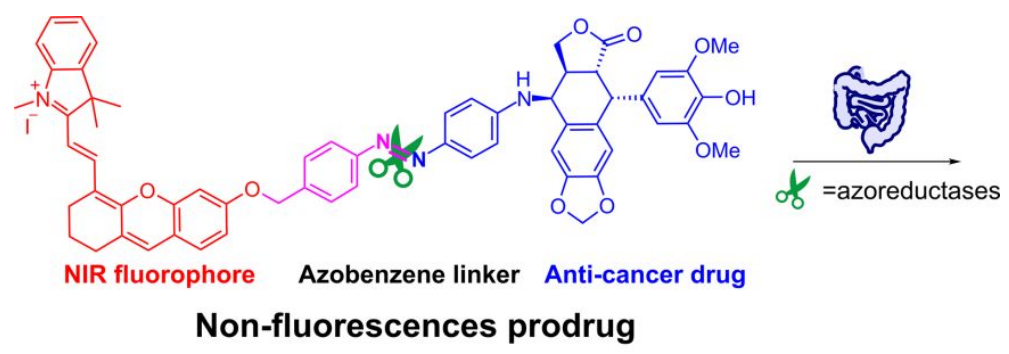

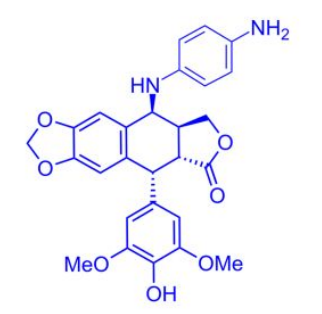

Directly release AdP

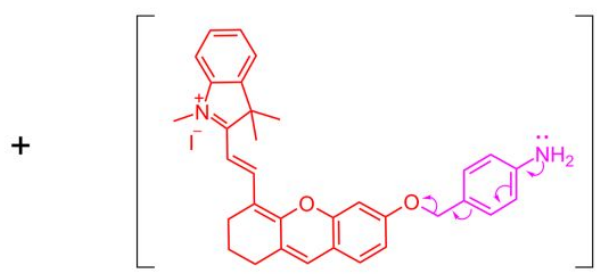

Cy intermediate

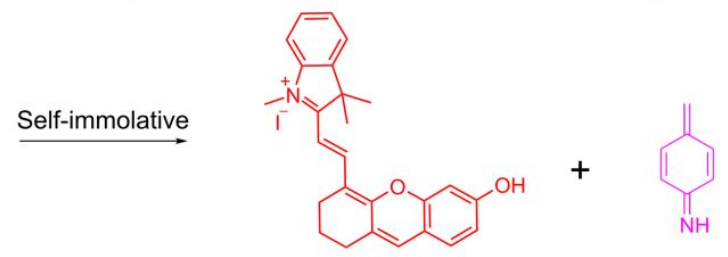

Cy

$\lambda_{\mathrm{em}}=708 \mathrm{~nm}$

Strong NIR fluorescence

Figure S5. Proposed release mechanism of the azo-based prodrug AP-N=N-Cy activated by azoreductases in colon. 


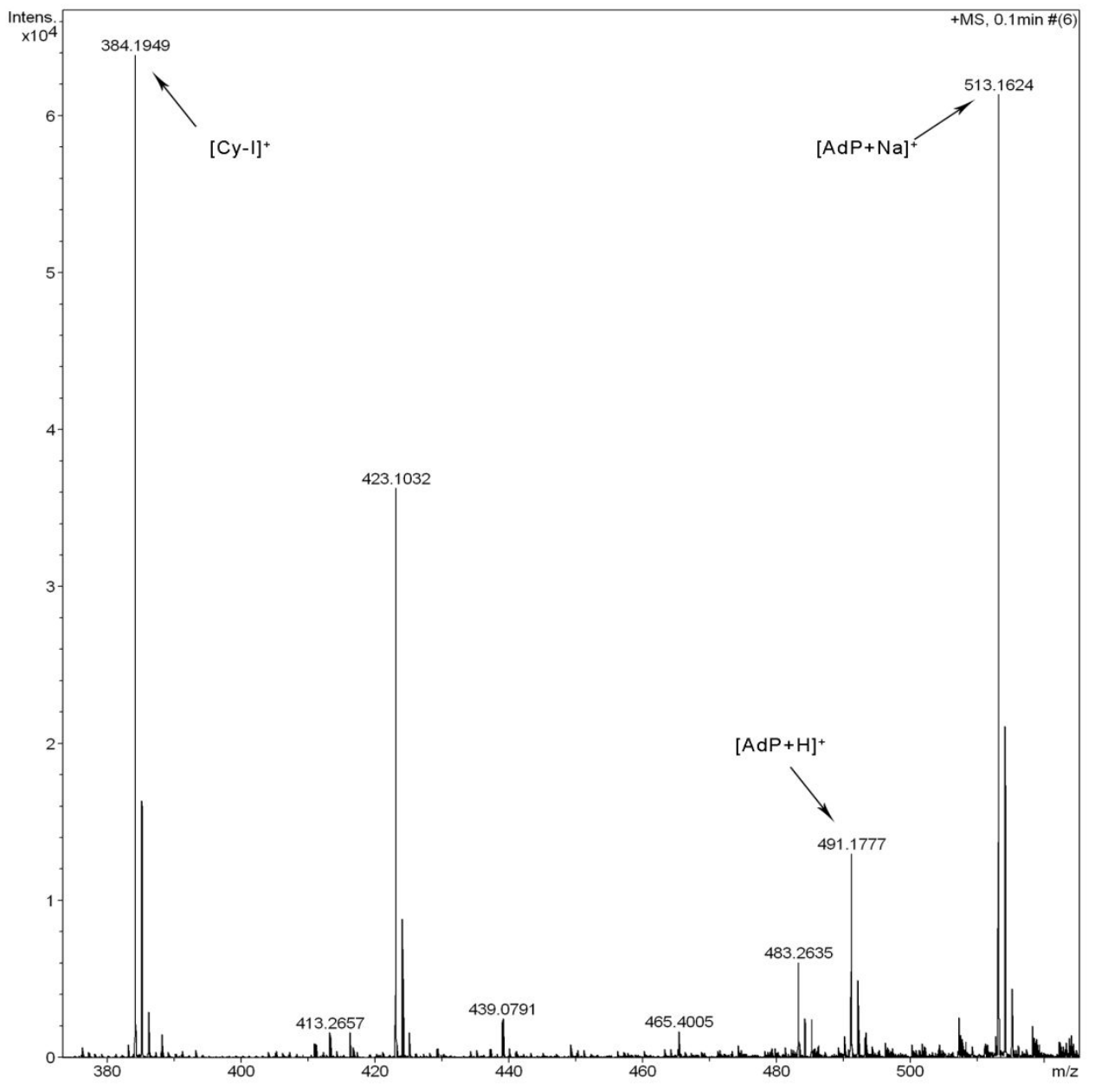

Figure S6. HRMS spectrum of the products from AP-N=N-Cy $(10 \mu \mathrm{M})$ after incubation with rat cecal contents $(1 \mathrm{~mL})$ for $12 \mathrm{~h}$ at $37{ }^{\circ} \mathrm{C}$.

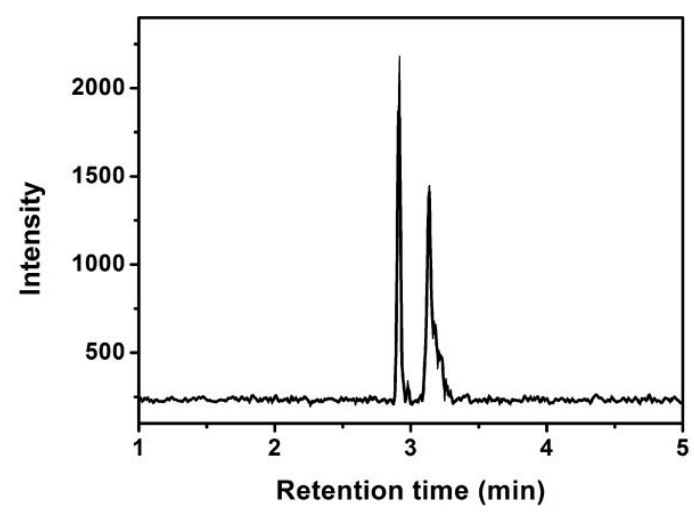

Figure S7. Typical UPLC chromatograms of AdP and Cy by monitoring the ESI-MS/MS fragments at $\mathrm{m} / \mathrm{z} 383.083$ (corresponding to AdP) and $\mathrm{m} / \mathrm{z} 120.417$ (corresponding to Cy). The retention time of AdP and $\mathrm{Cy}$ is $2.92 \mathrm{~min}$ and 3.14 min respectively. 

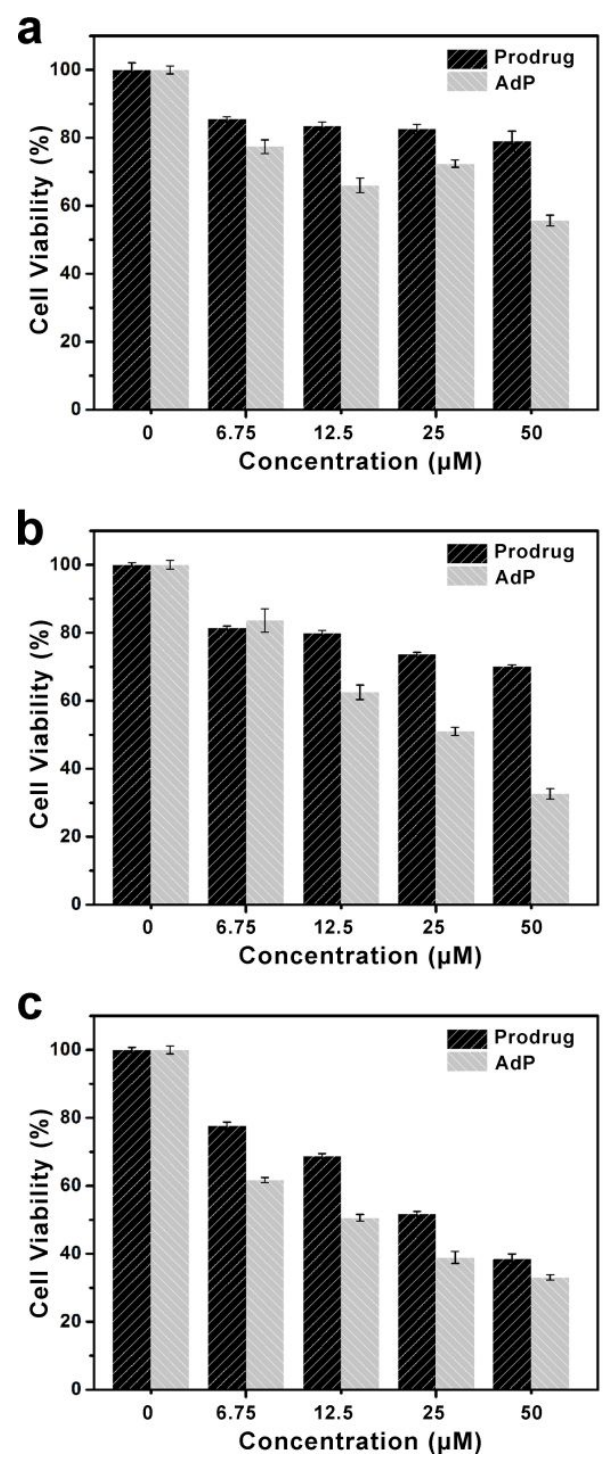

Figure S8. Relative cell viability of HeLa cells (a), HCT 116 cells (b) and Hep G2 cells (c) after incubating with various concentrations of AP-N=N-Cy and AdP for $24 \mathrm{~h}$.

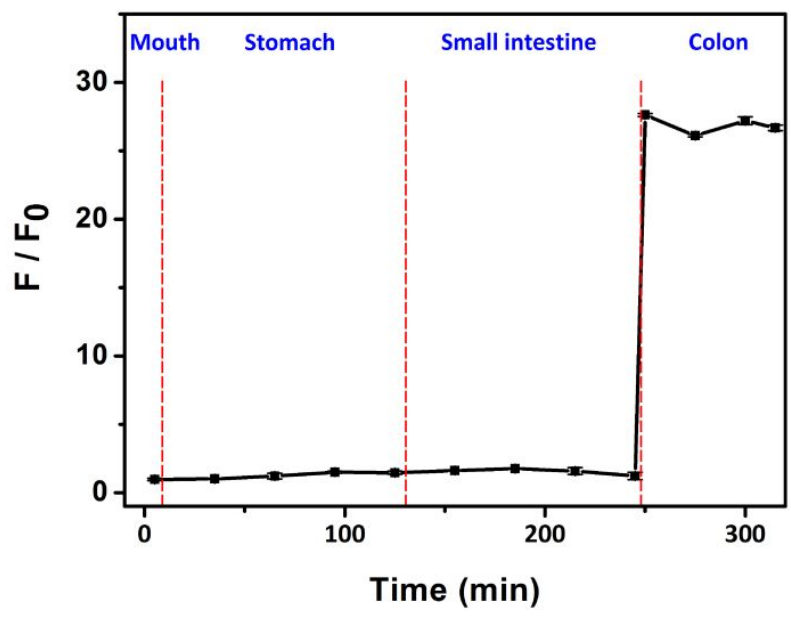

Figure S9. Fluorescence changes of prodrug AP-N=N-Cy after incubation with stimulated saliva fluid, gastric fluid, duodenal fluid and colon fluid. 
a

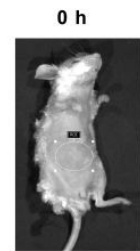

$12 \mathrm{~h}$

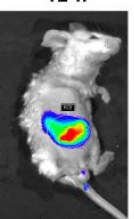

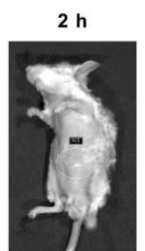
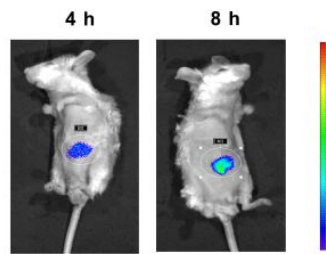

$16 \mathrm{~h}$

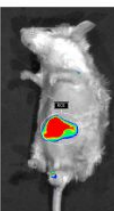

$20 \mathrm{~h}$

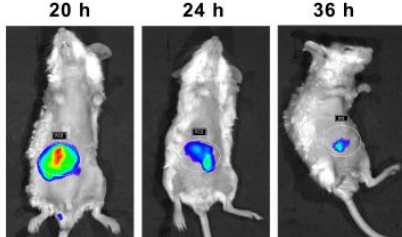

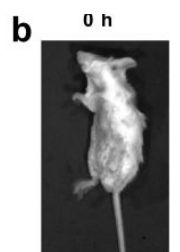
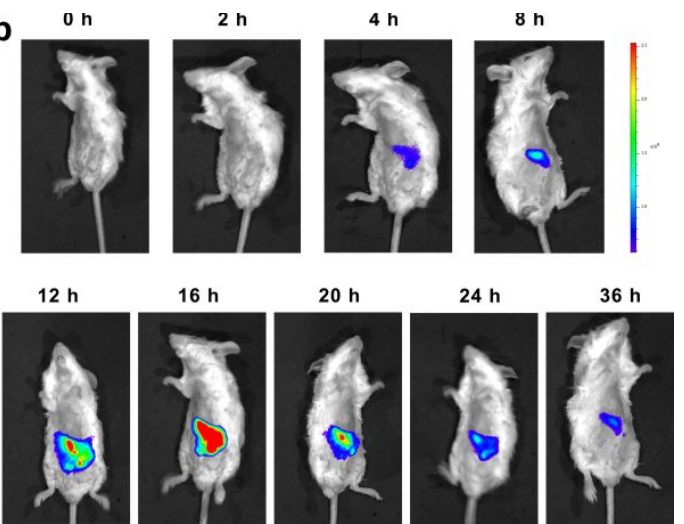

Figure S10. In vivo fluorescence images of mice at various time points after gavage with $\mathrm{AP}-\mathrm{N}=\mathrm{N}-\mathrm{Cy}(0.1 \mathrm{~mL}, 2 \mathrm{mg} / \mathrm{kg})$.
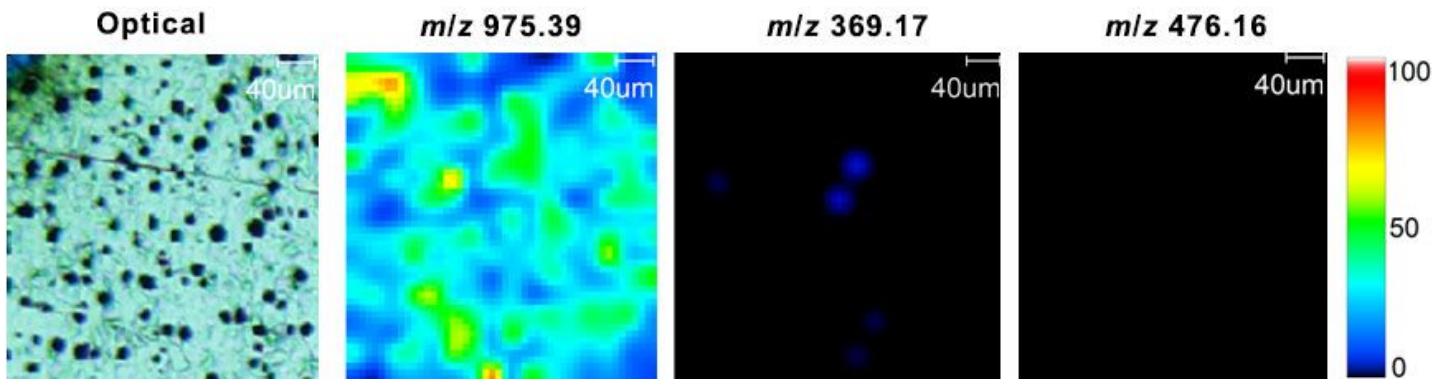

Figure S11. Imaging mass spectrometry of $\mathrm{AP}-\mathrm{N}=\mathrm{N}-\mathrm{Cy}$ on a target plate without any azoreductase, Optical, IMS of AP-N=N-Cy $(\mathrm{m} / \mathrm{z}$ 975.39), Cy $(\mathrm{m} / \mathrm{z}$ 369.17) and AdP $(\mathrm{m} / \mathrm{z}$ 476.16).
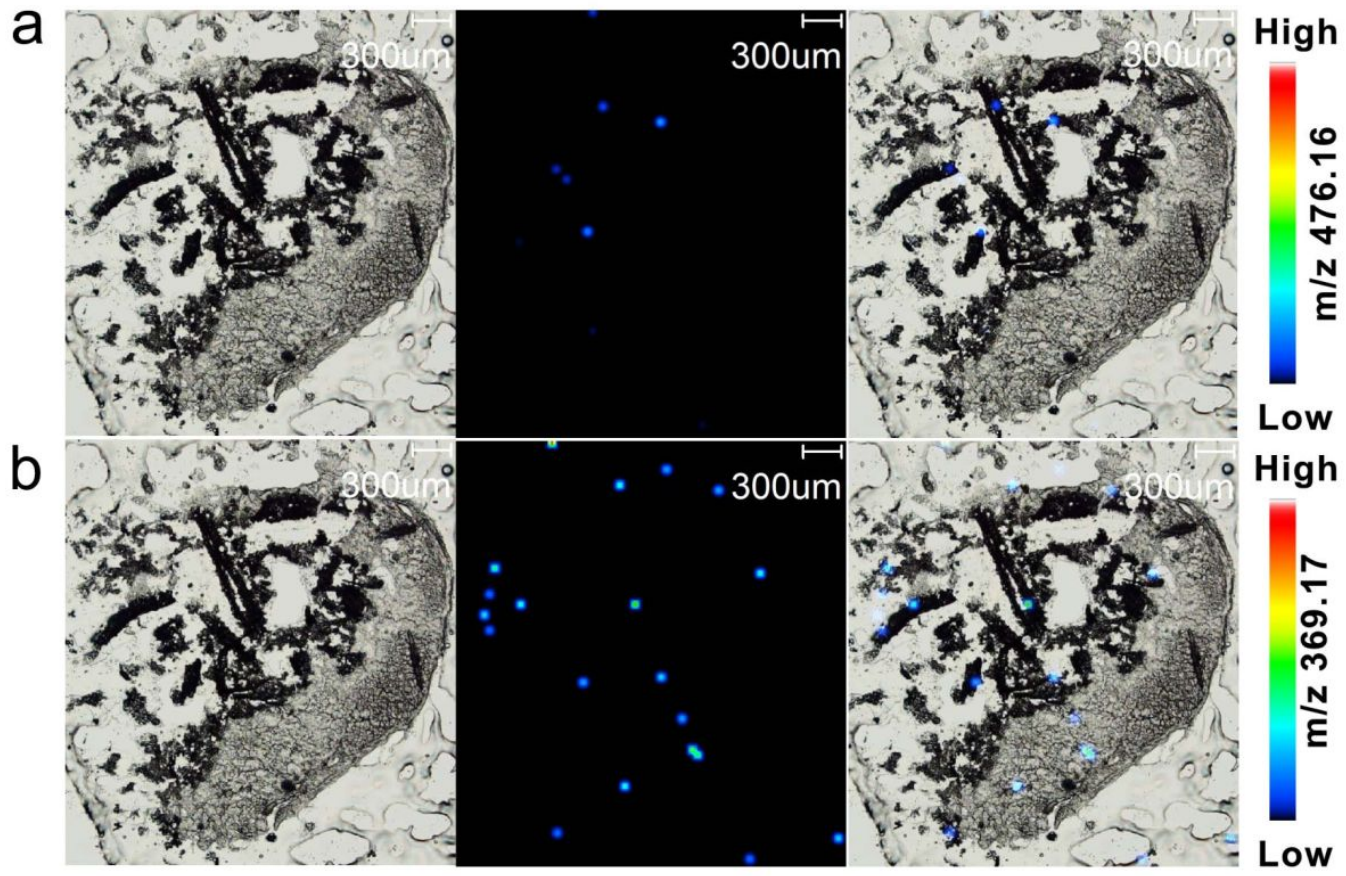

Figure S12. Imaging mass spectrometry of mice colon tissue at $12 \mathrm{~h}$ after gavage PBS. (a) optical image of the colon tissue section and IMS images of AdP (MS/MS fragmentation, $\mathrm{m} / \mathrm{z}$ 476.16) and Cy (b) (MS/MS fragmentation, $m / z$ 369.17). 


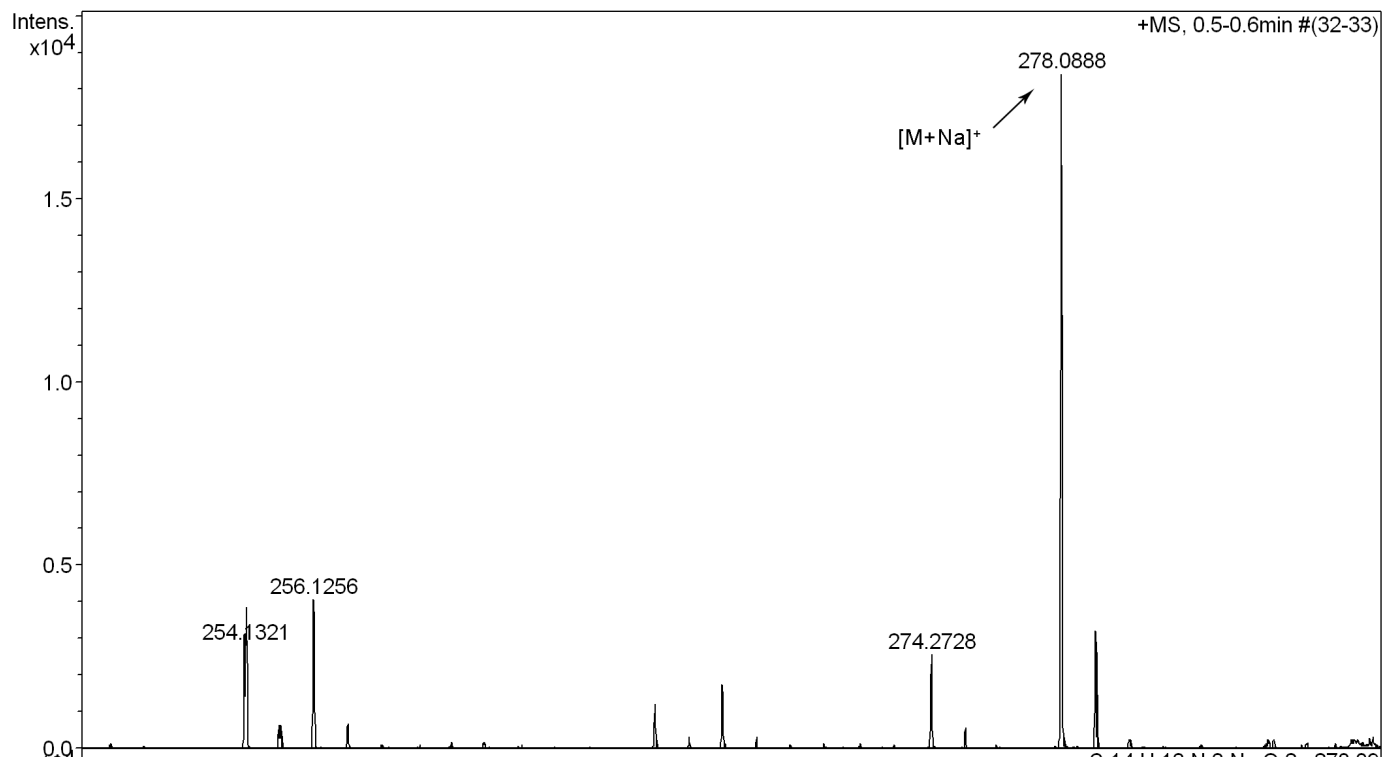

Figure S15. HRMS spectrum of compound 1.

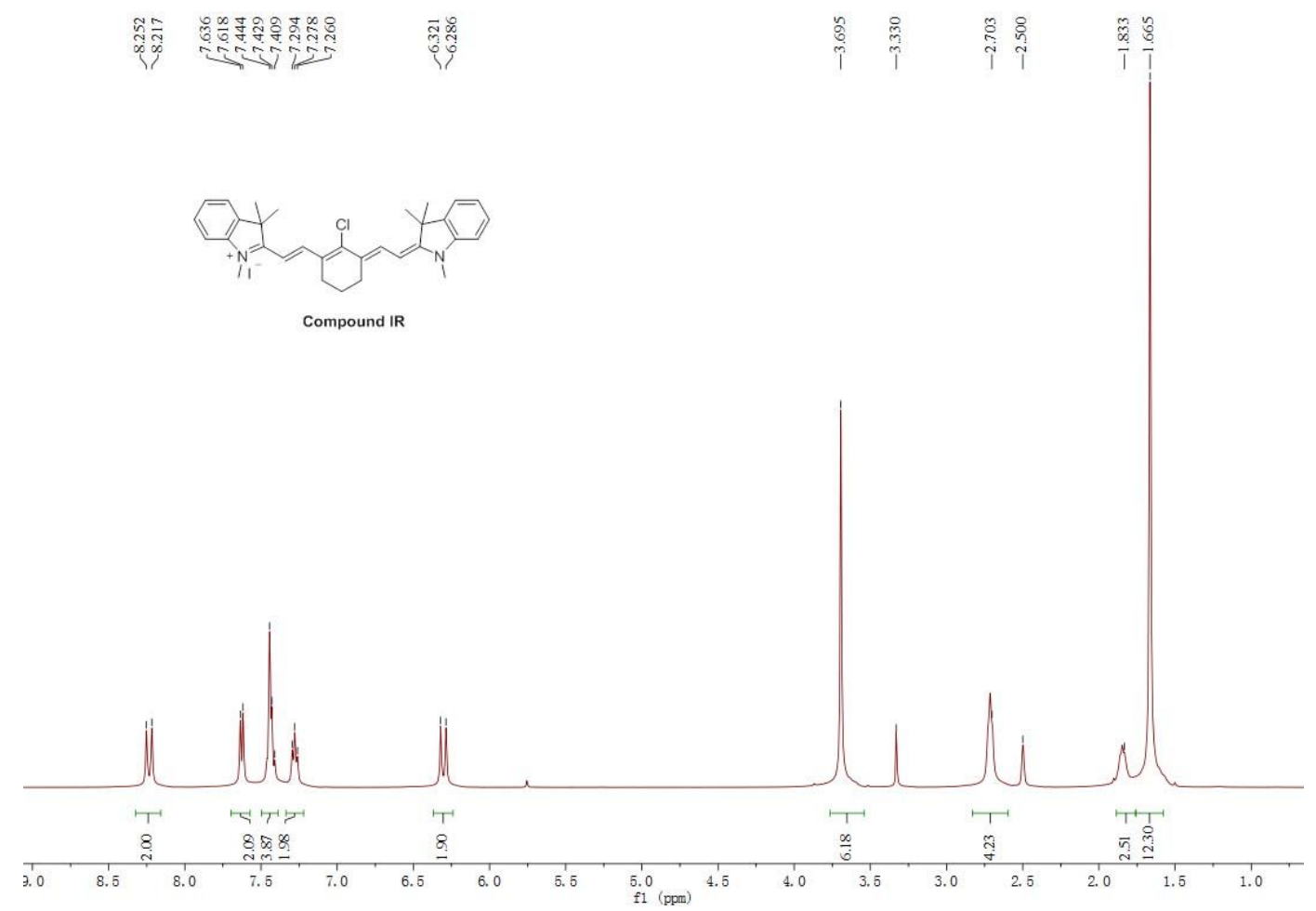

Figure S16. ${ }^{1} \mathrm{H}$ NMR spectrum of compound IR in DMSO-d6. 

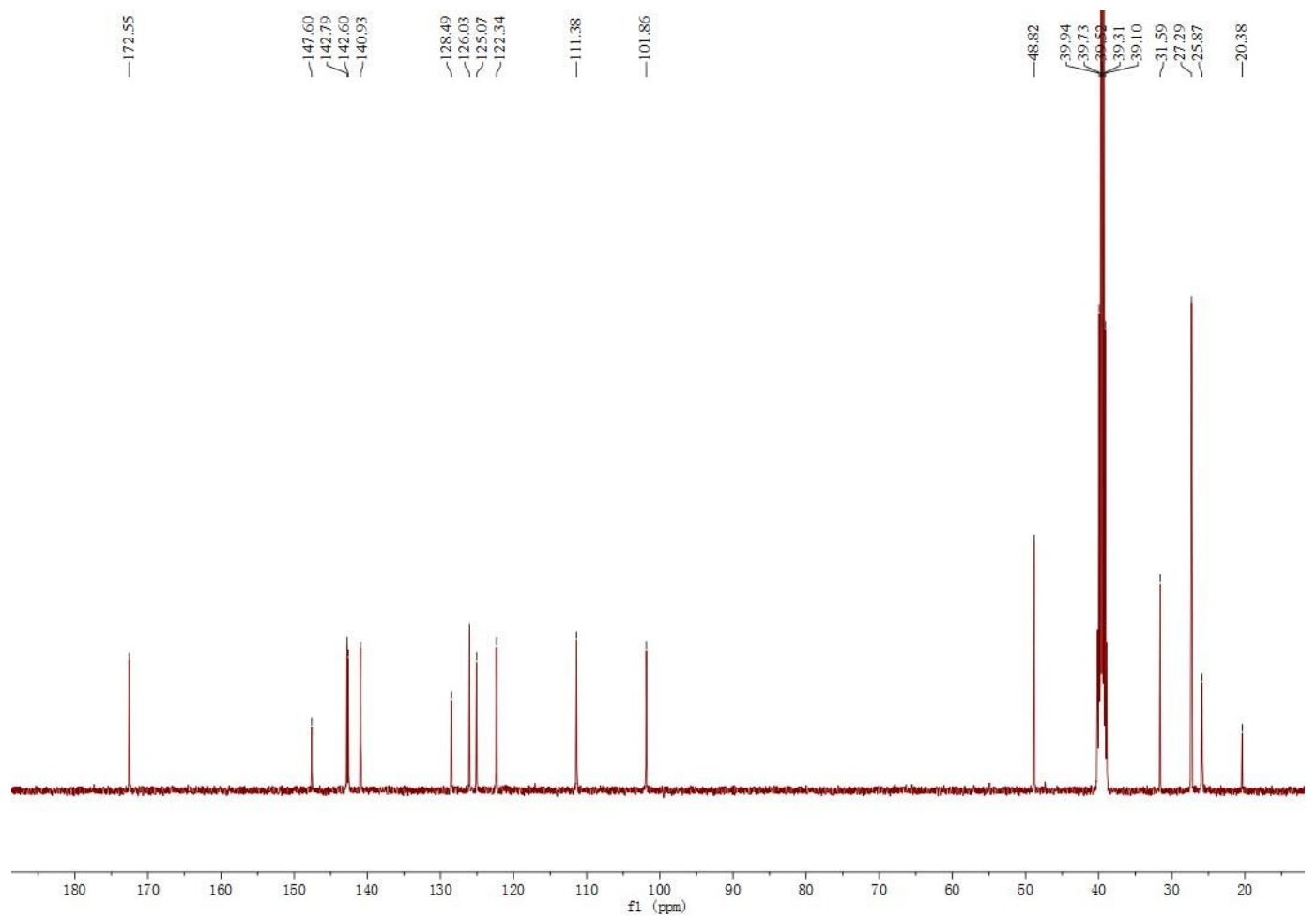

Figure S17. ${ }^{13} \mathrm{C}$ NMR spectrum of compound IR in DMSO- $d 6$.

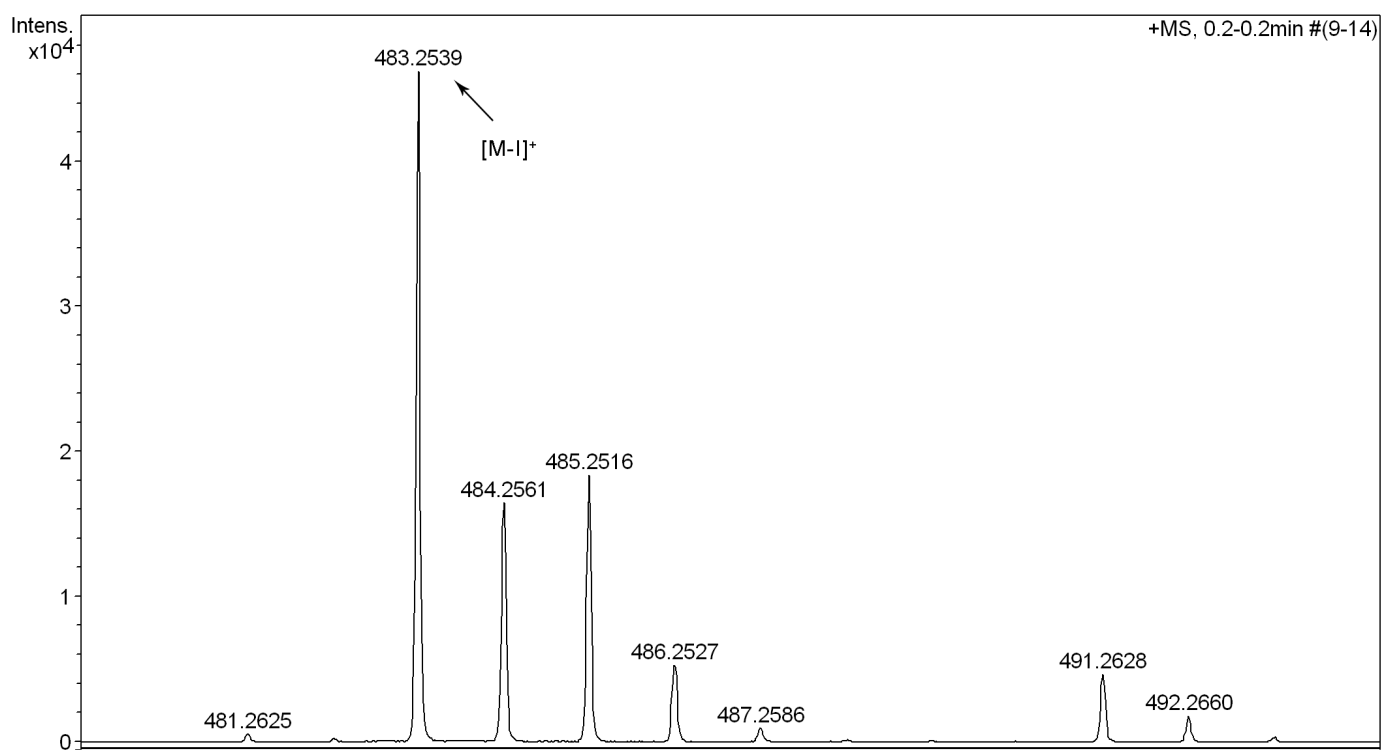

Figure S18. HRMS spectrum of compound IR. 


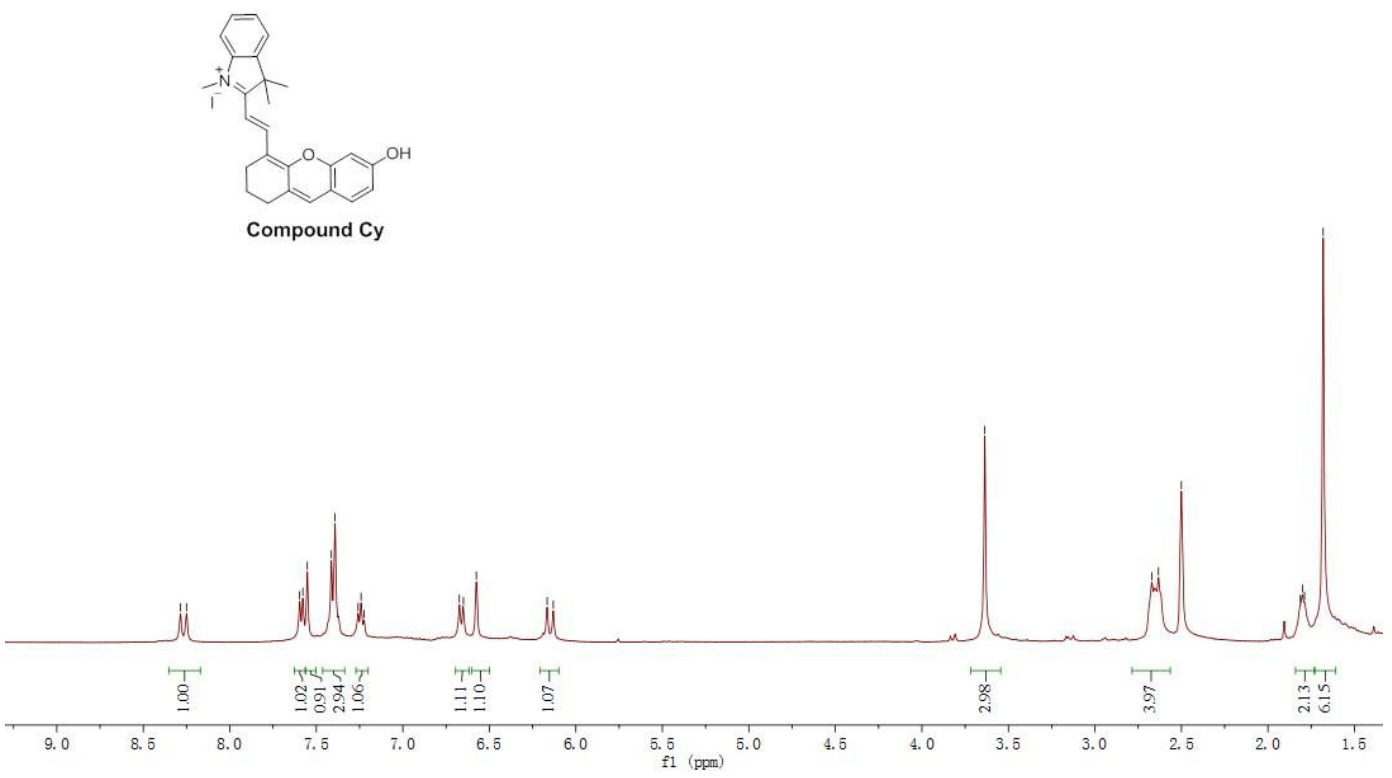

Figure S19. ${ }^{1} \mathrm{H}$ NMR spectrum of compound Cy in DMSO- $d 6$.

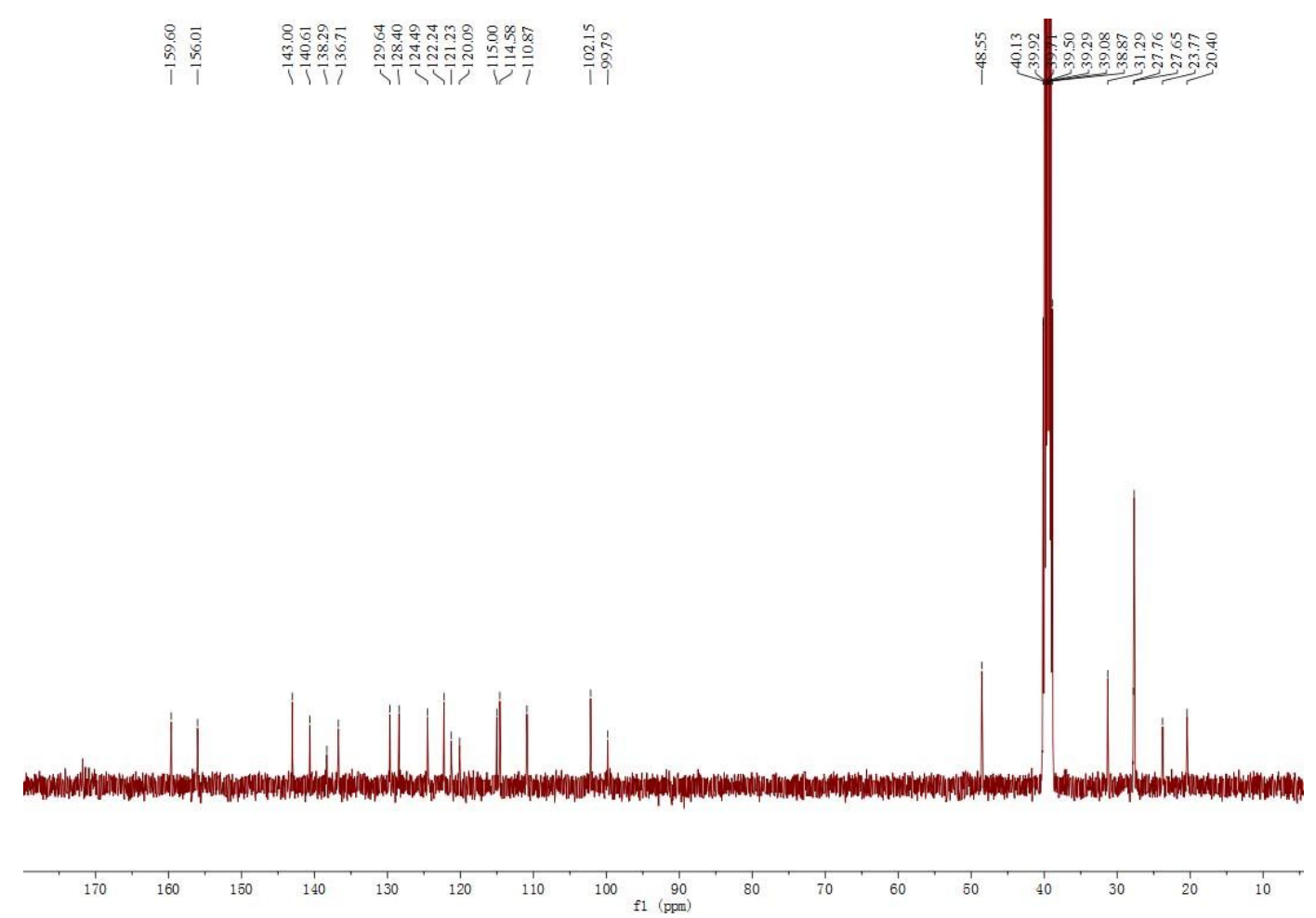

Figure S20. ${ }^{13} \mathrm{C}$ NMR spectrum of compound Cy in DMSO- $d 6$. 


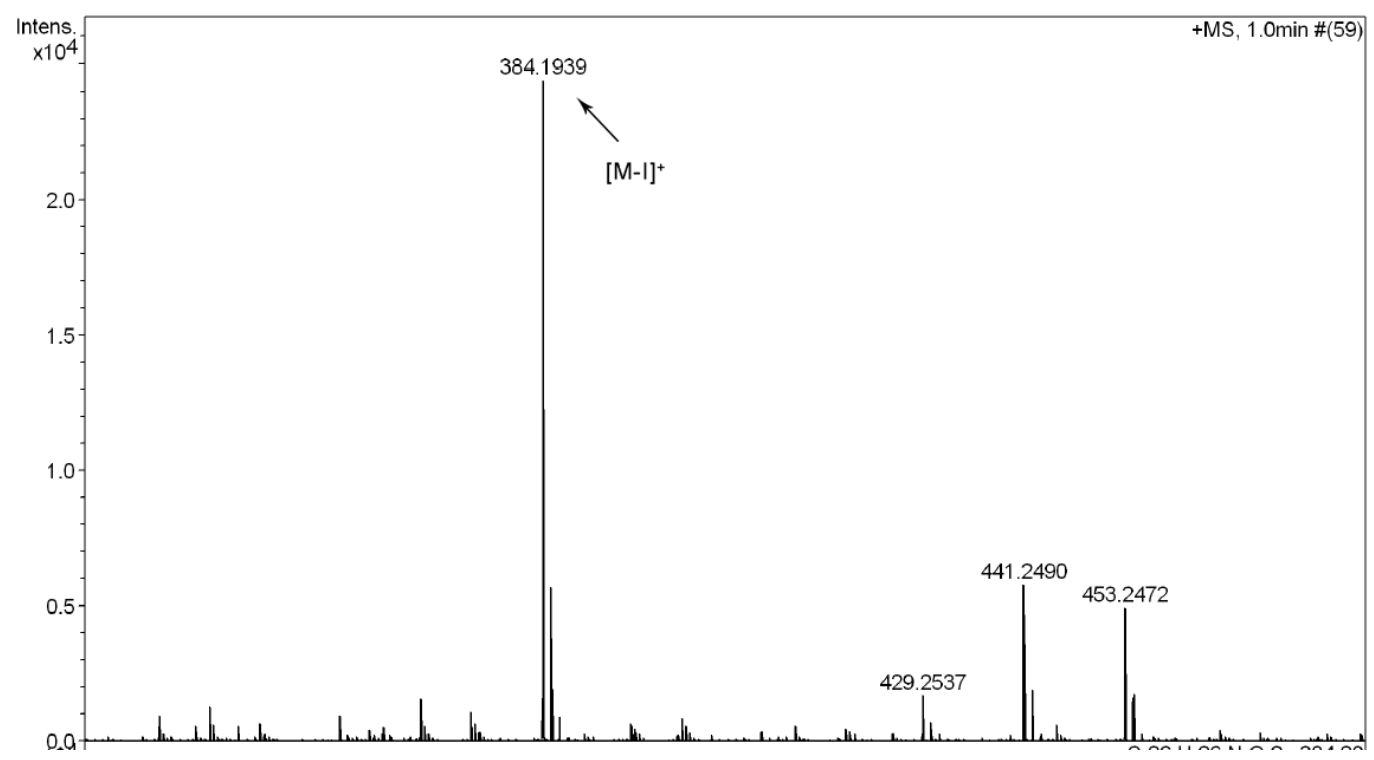

Figure S21. HRMS spectrum of compound Cy.
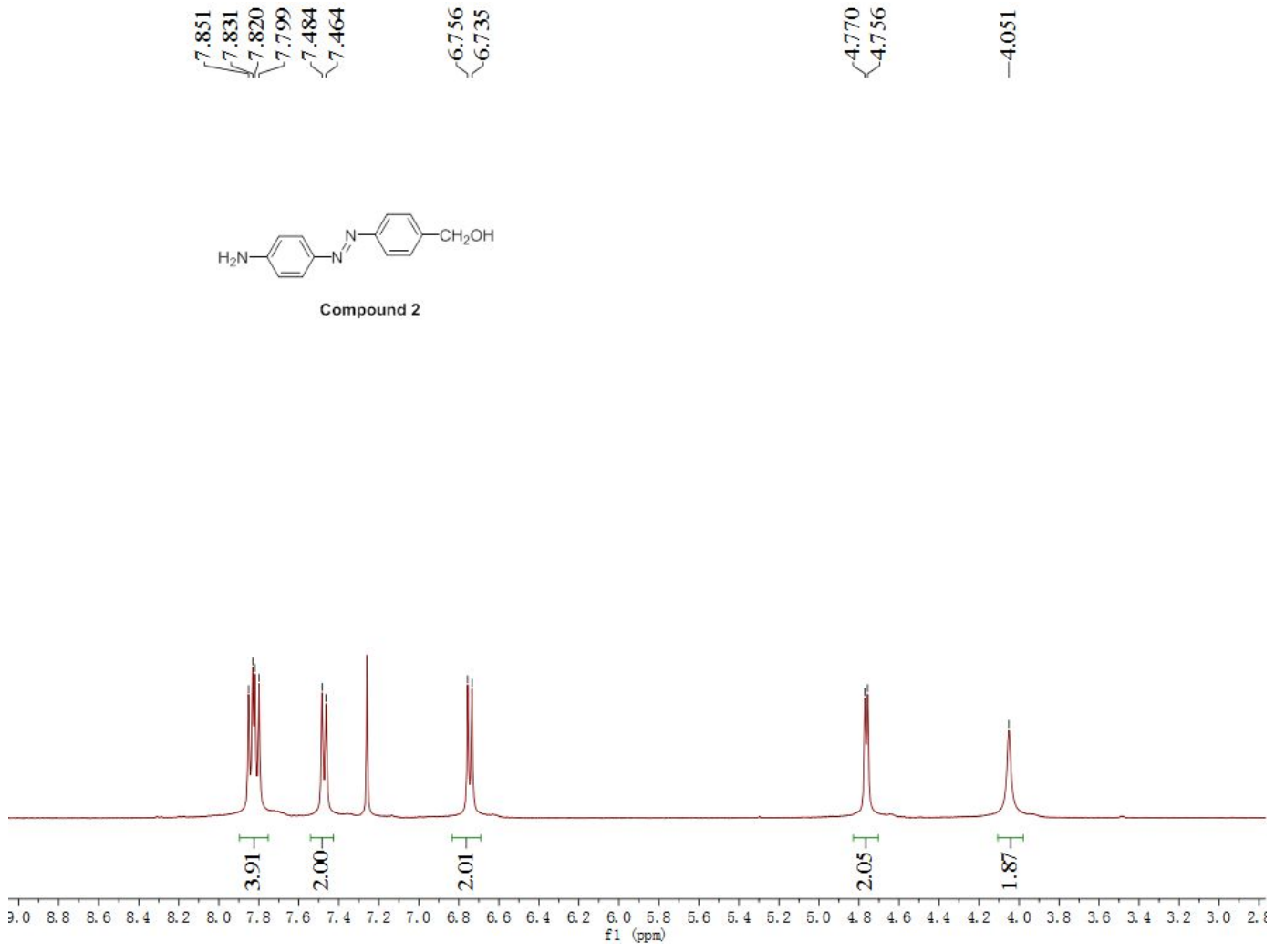

Figure S22. ${ }^{1} \mathrm{H}$ NMR spectrum of compound 2 in $\mathrm{CDCl}_{3}$. 


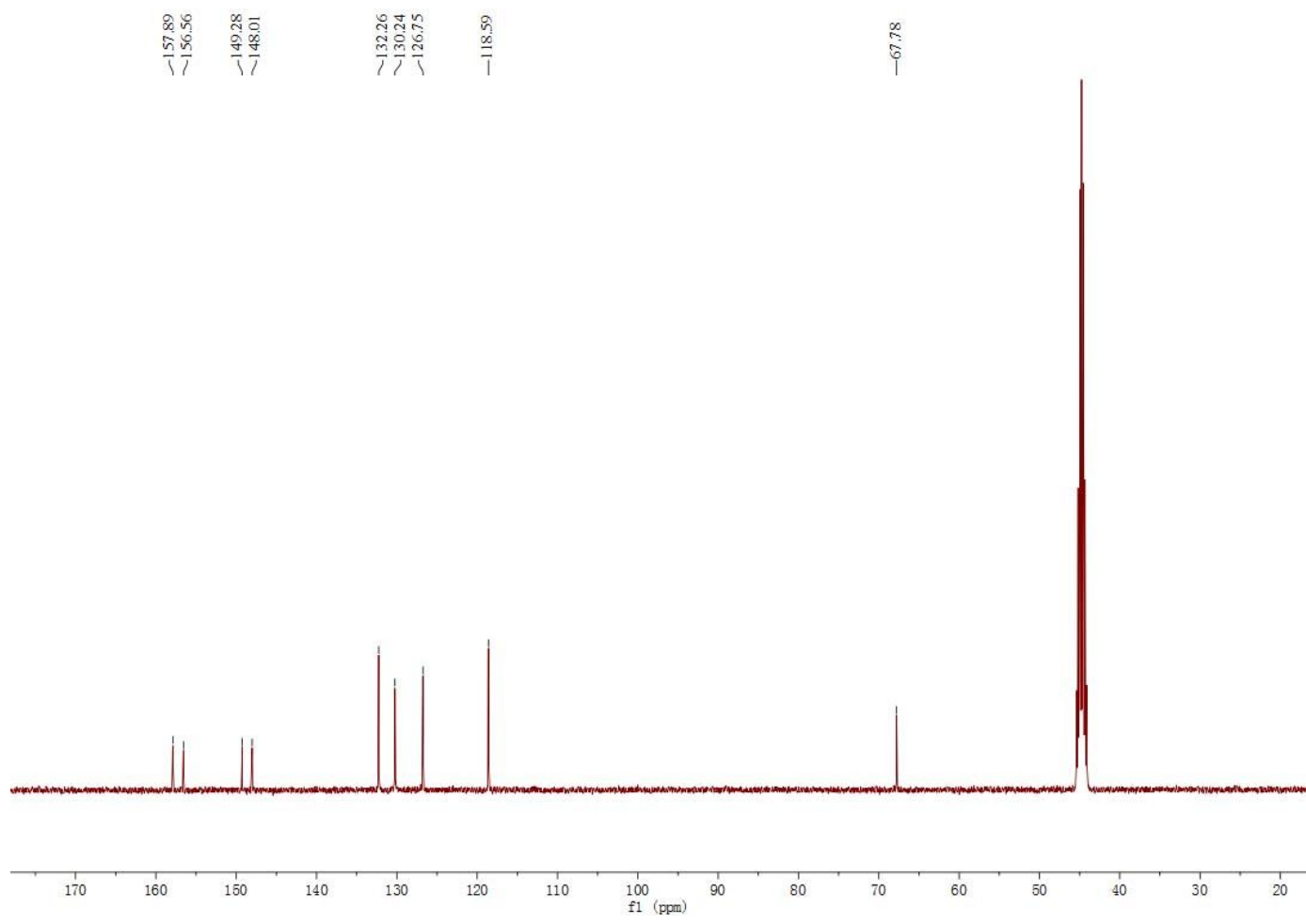

Figure S23. ${ }^{13} \mathrm{C}$ NMR spectrum of compound 2 in $\mathrm{CDCl}_{3}$.

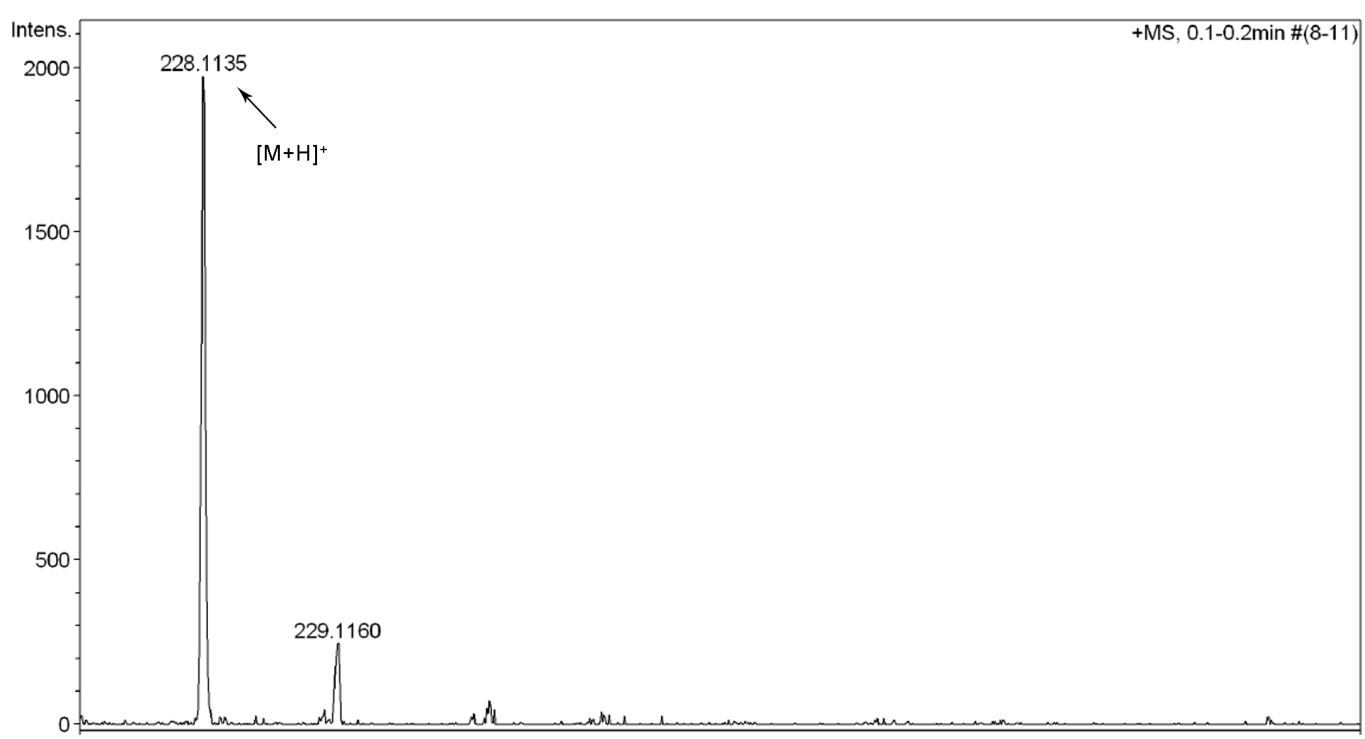

Figure S24. HRMS spectrum of compound 2. 

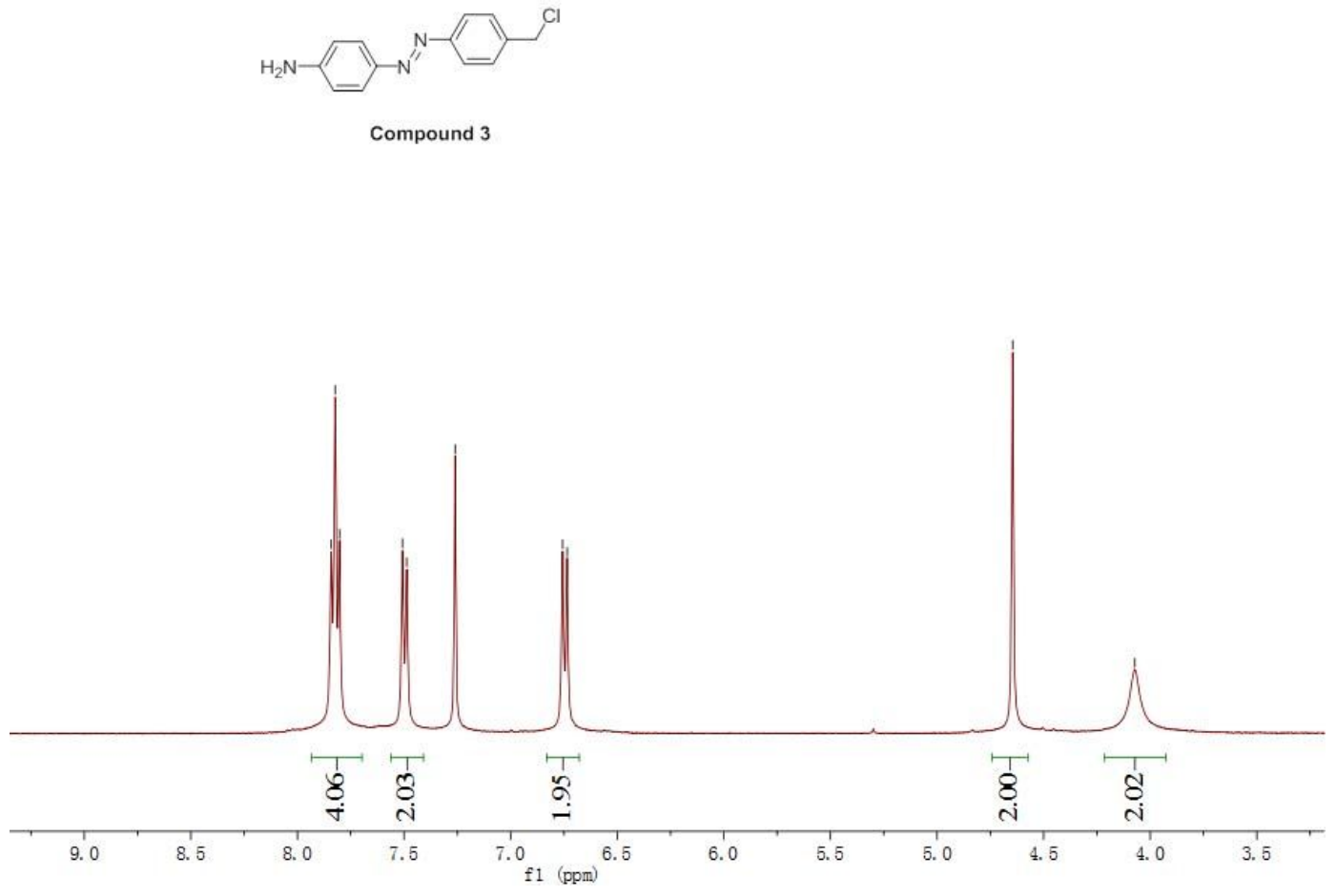

Figure S25. ${ }^{13} \mathrm{C}$ NMR spectrum of compound 3 in $\mathrm{CDCl}_{3}$.

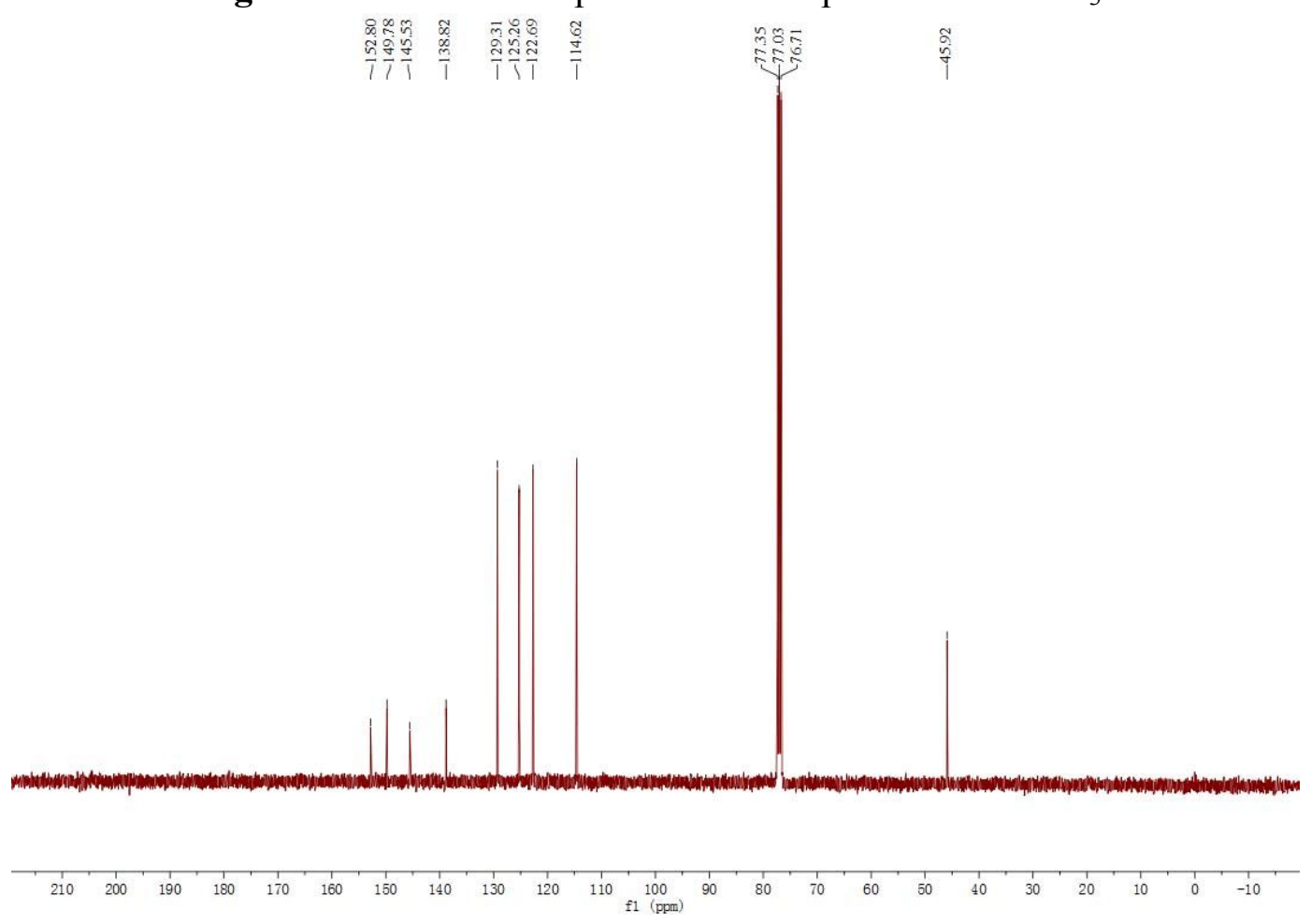

Figure S26. ${ }^{13} \mathrm{C}$ NMR spectrum of compound 3 in $\mathrm{CDCl}_{3}$. 


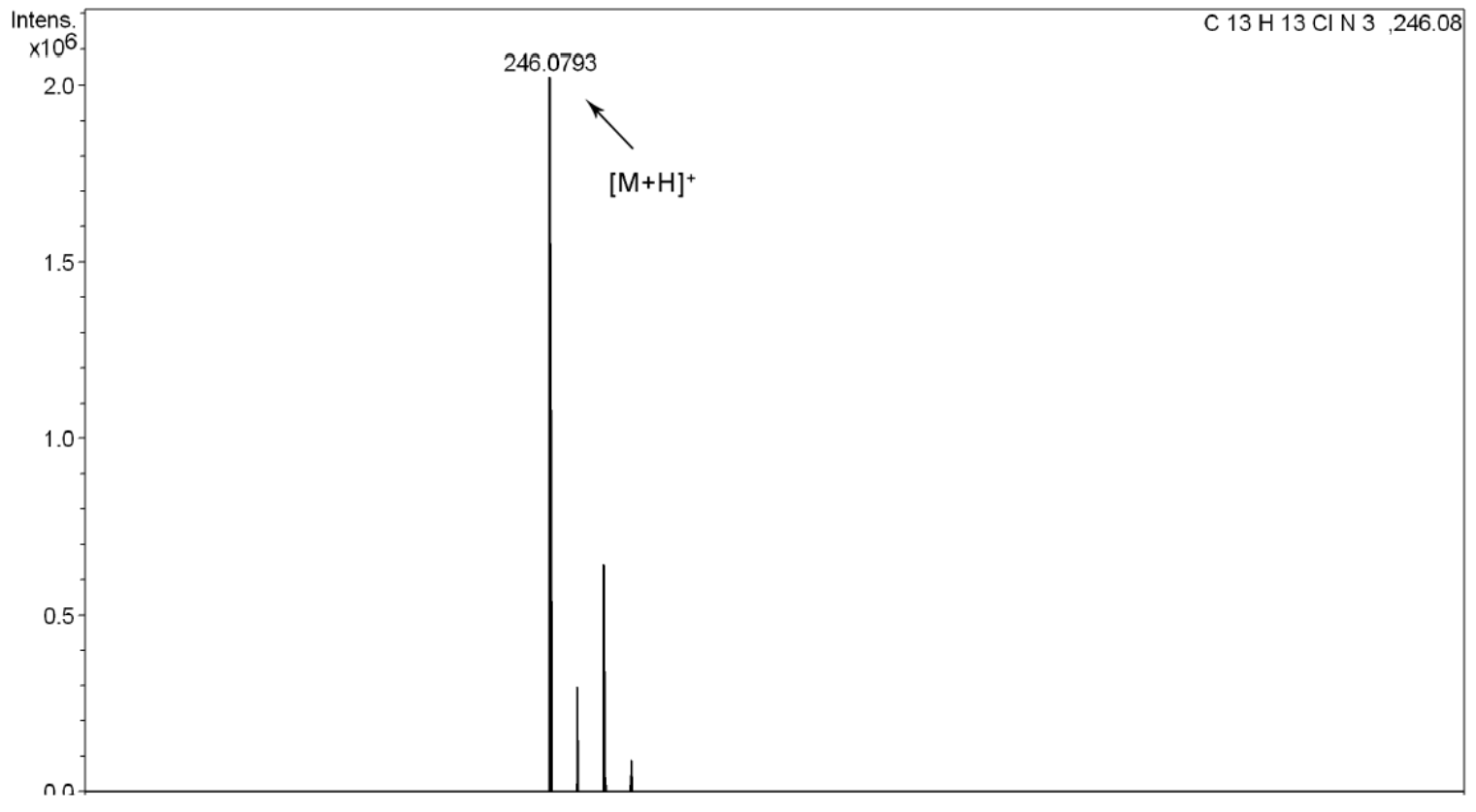

Figure S27. HRMS spectrum of compound 3.

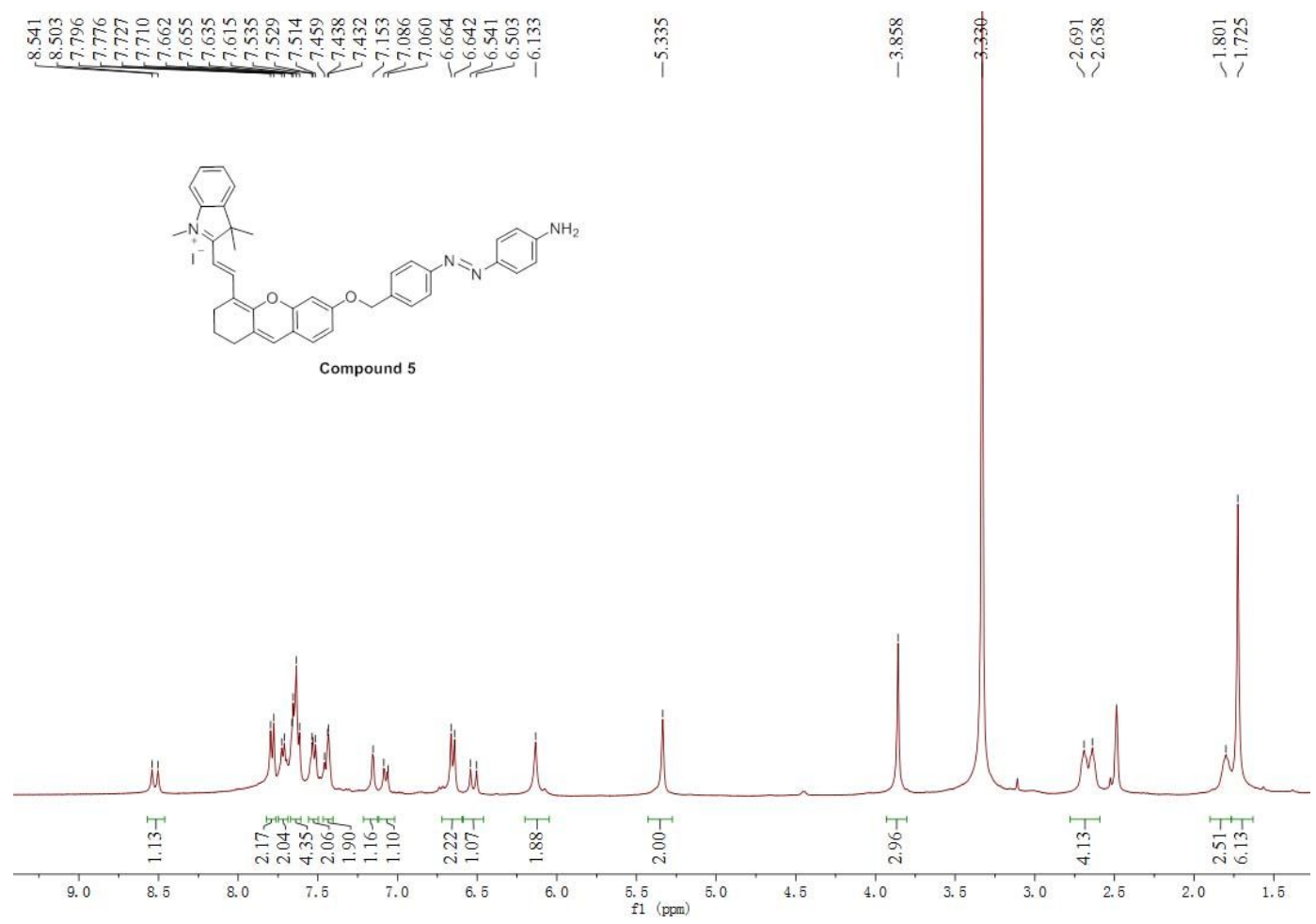

Figure S28. ${ }^{1} \mathrm{H}$ NMR spectrum of compound 5 in DMSO- $d 6$. 


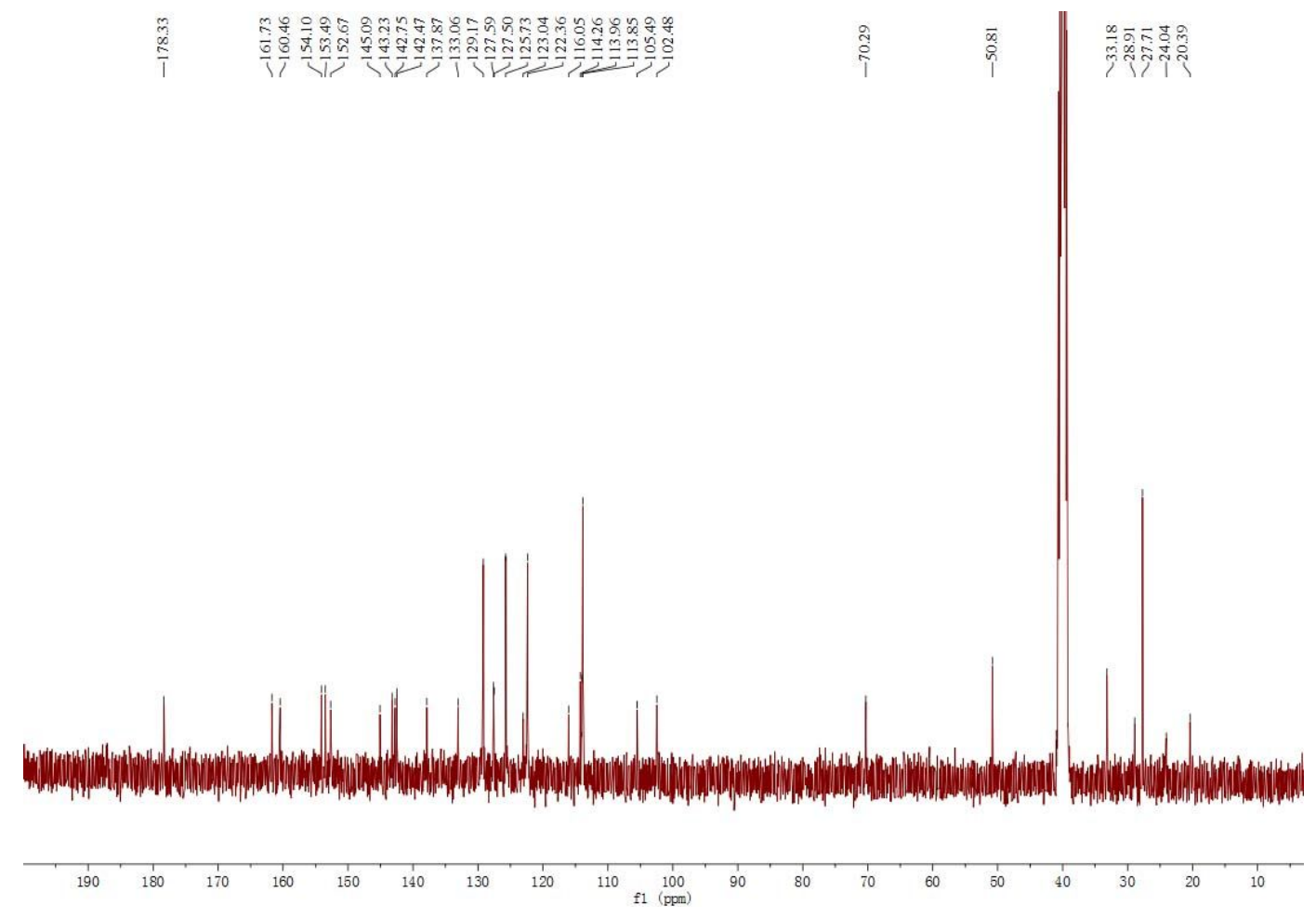

Figure S29. ${ }^{13} \mathrm{C}$ NMR spectrum of compound 5 in DMSO- $d 6$.

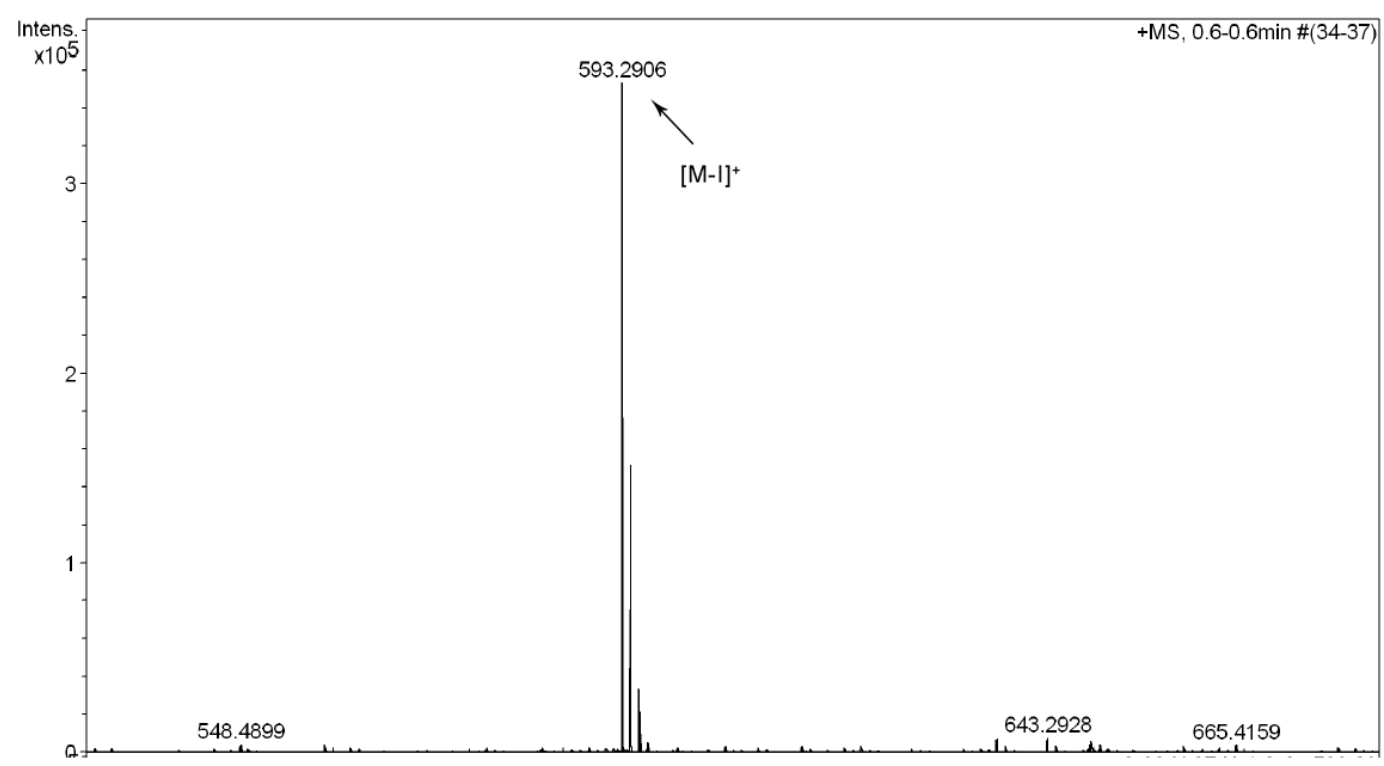

Figure S30. HRMS spectrum of compound $\mathbf{5}$. 

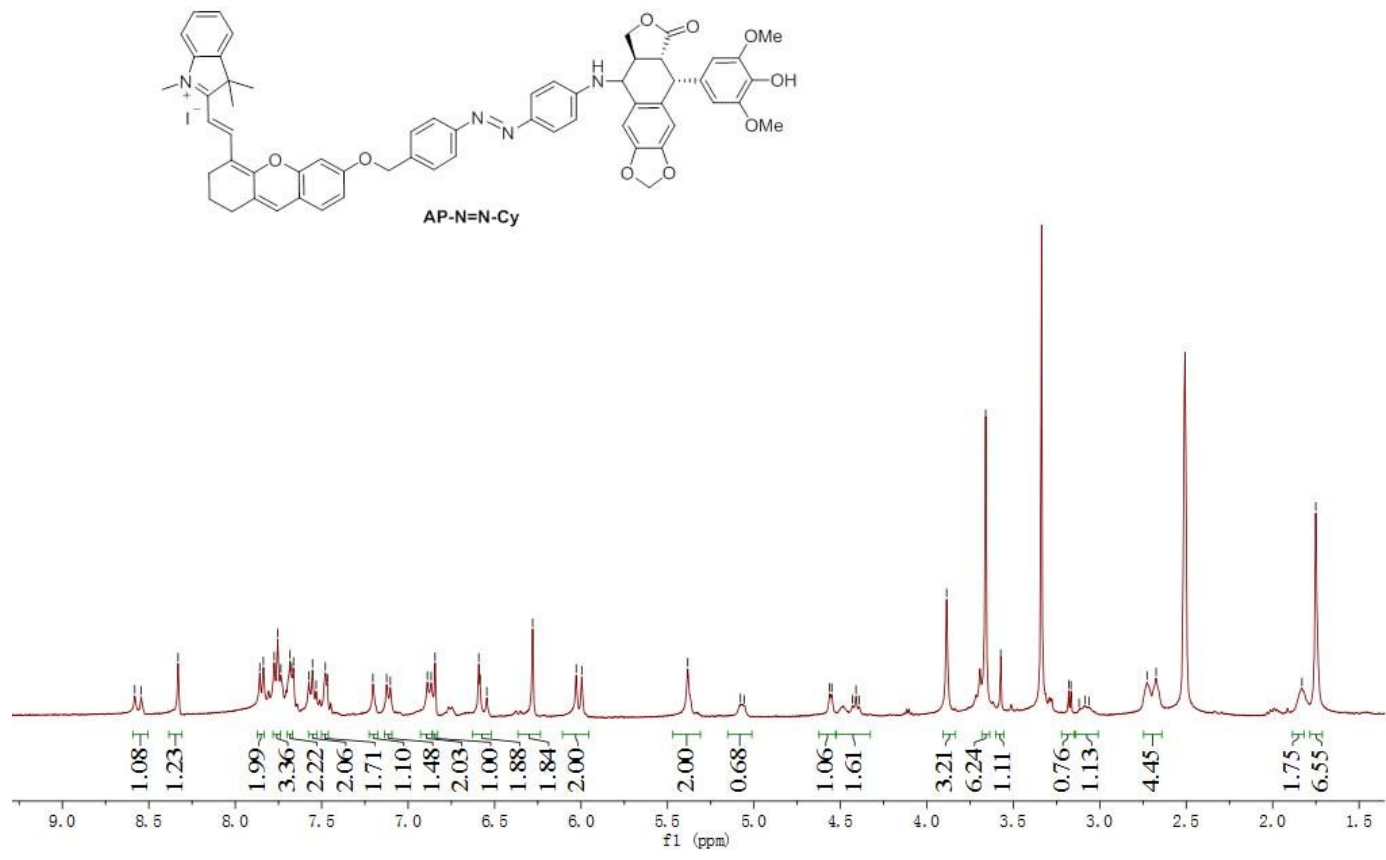

Figure S31. ${ }^{1} \mathrm{H}$ NMR spectrum of prodrug AP-N=N-Cy in DMSO-d6.
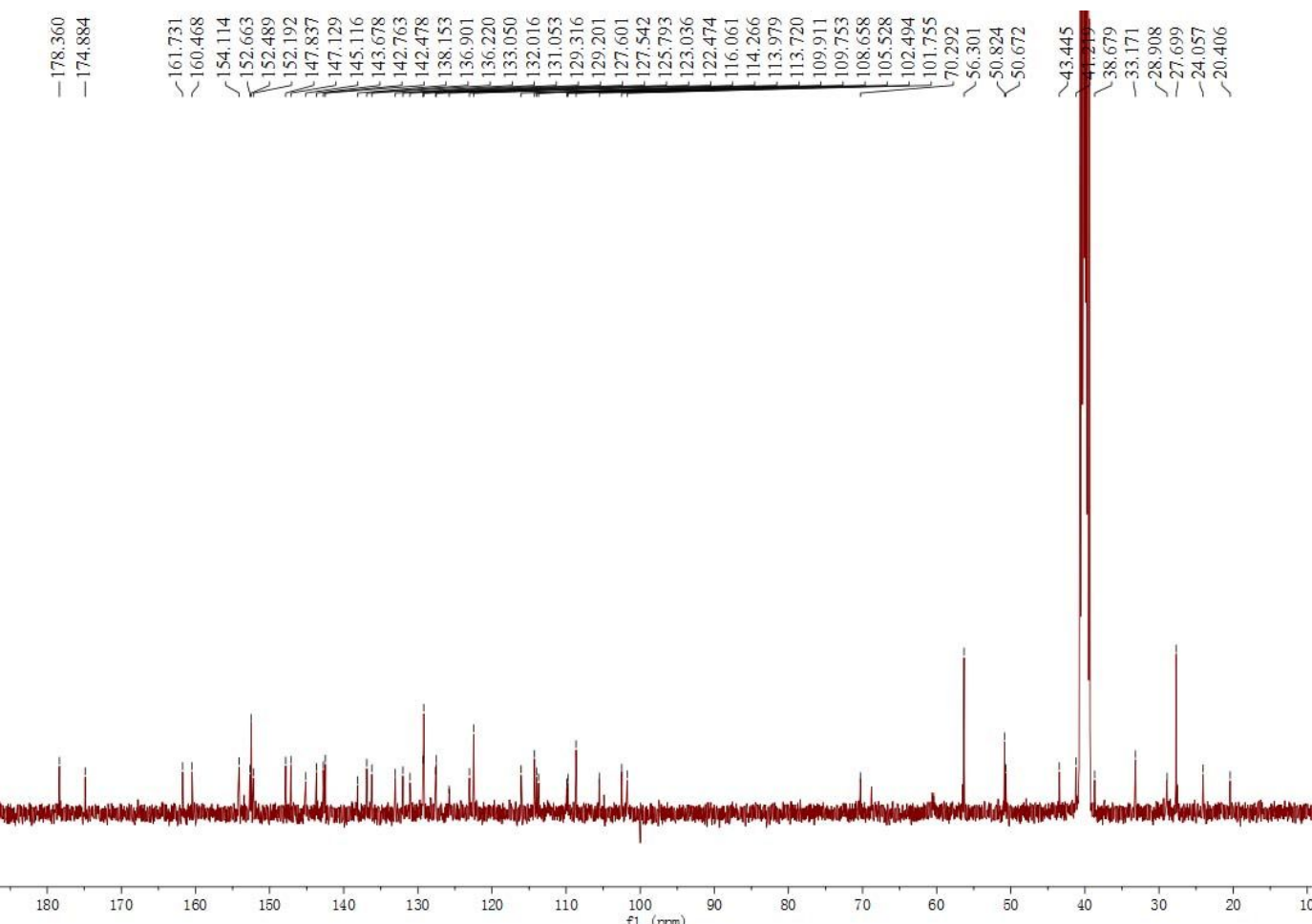

Figure S32. ${ }^{13} \mathrm{C}$ NMR spectrum of prodrug AP-N=N-Cy in DMSO-d6. 


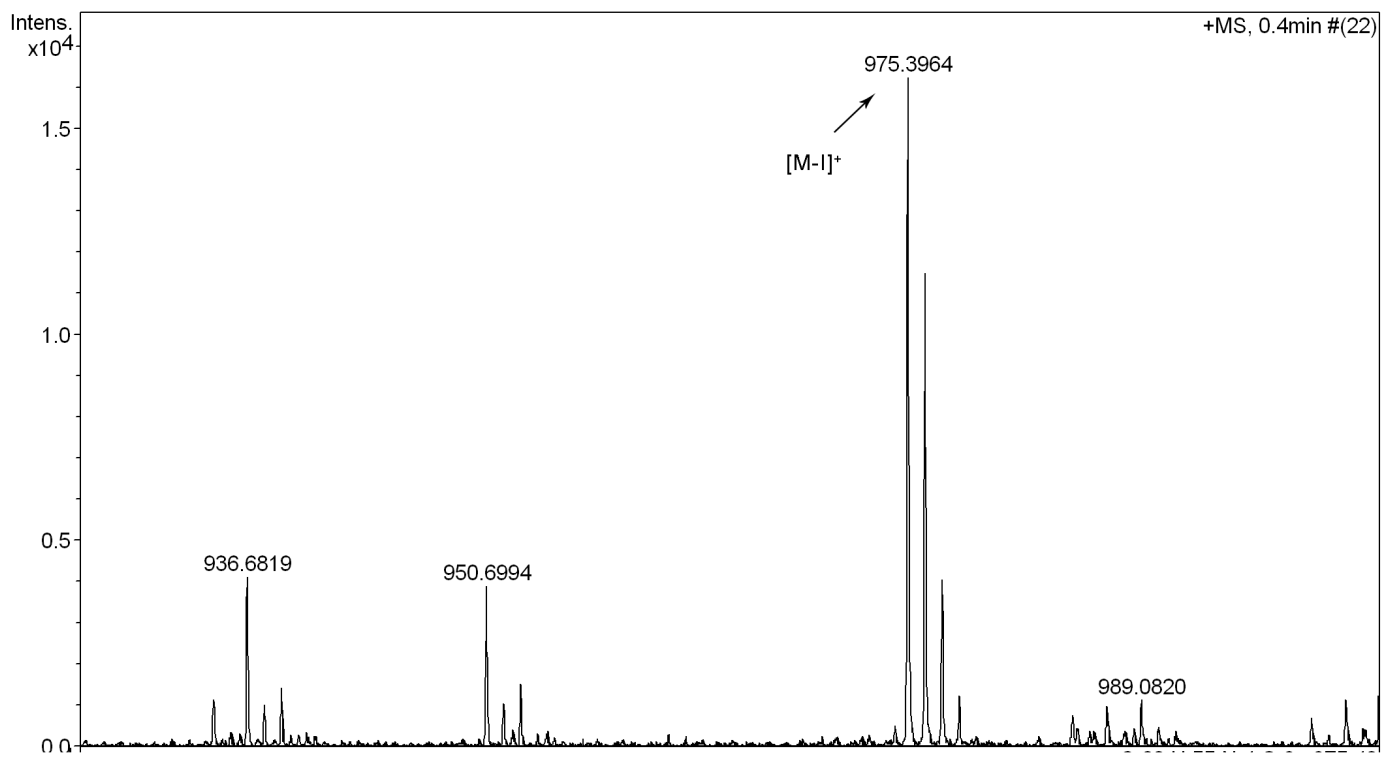

Figure S33. HRMS spectrum of prodrug AP-N=N-Cy. 


\section{HPLC traces of prodrug AP-N=N-Cy and some important}

\section{synthetic intermediates}

\section{Compound 2}

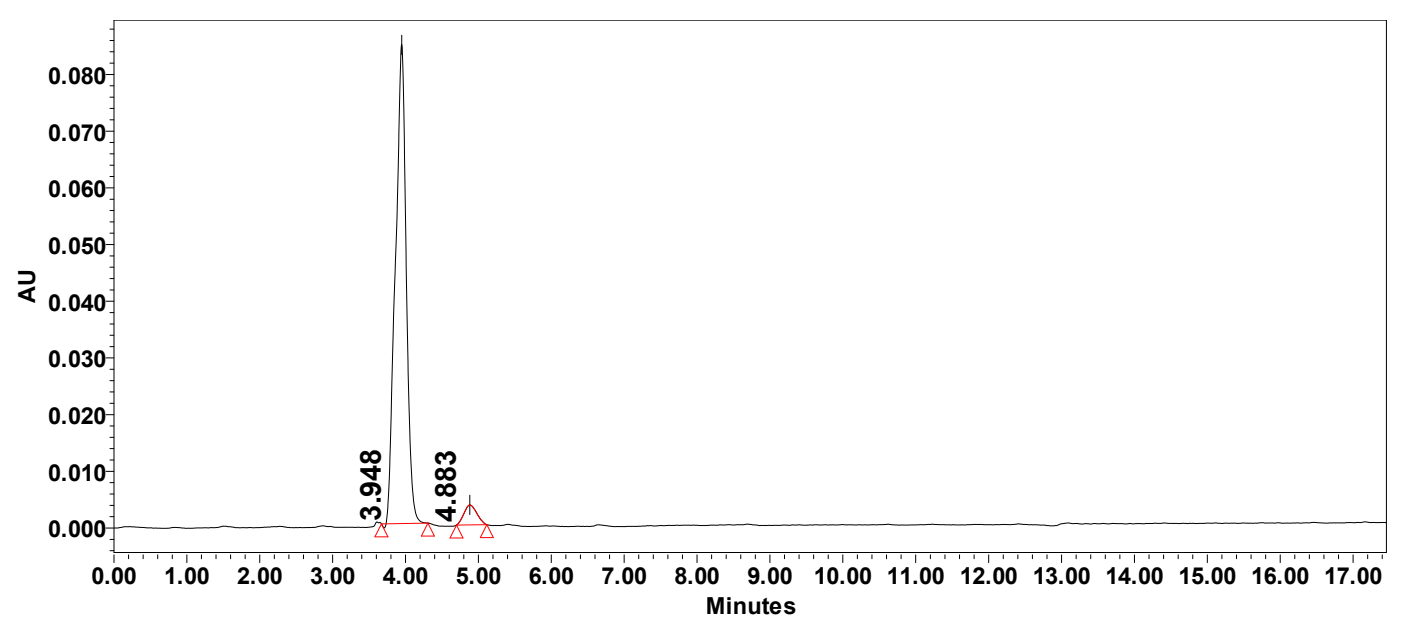

\begin{tabular}{cccc}
\hline Retention time & Height & Area & Area Percent (\%) \\
\hline 3.948 & 84516 & 870228 & 95.28 \\
4.883 & 3521 & 43064 & 4.72 \\
\hline
\end{tabular}

Compound 2. The flow rate was $1.0 \mathrm{~mL} / \mathrm{min}$ and detection at $383 \mathrm{~nm}$. The mobile phase was a mixture of methanol and $0.1 \%$ triethylamine aqueous solutions (17:3, $\mathrm{v} / \mathrm{v})$.

\section{Compound 3}

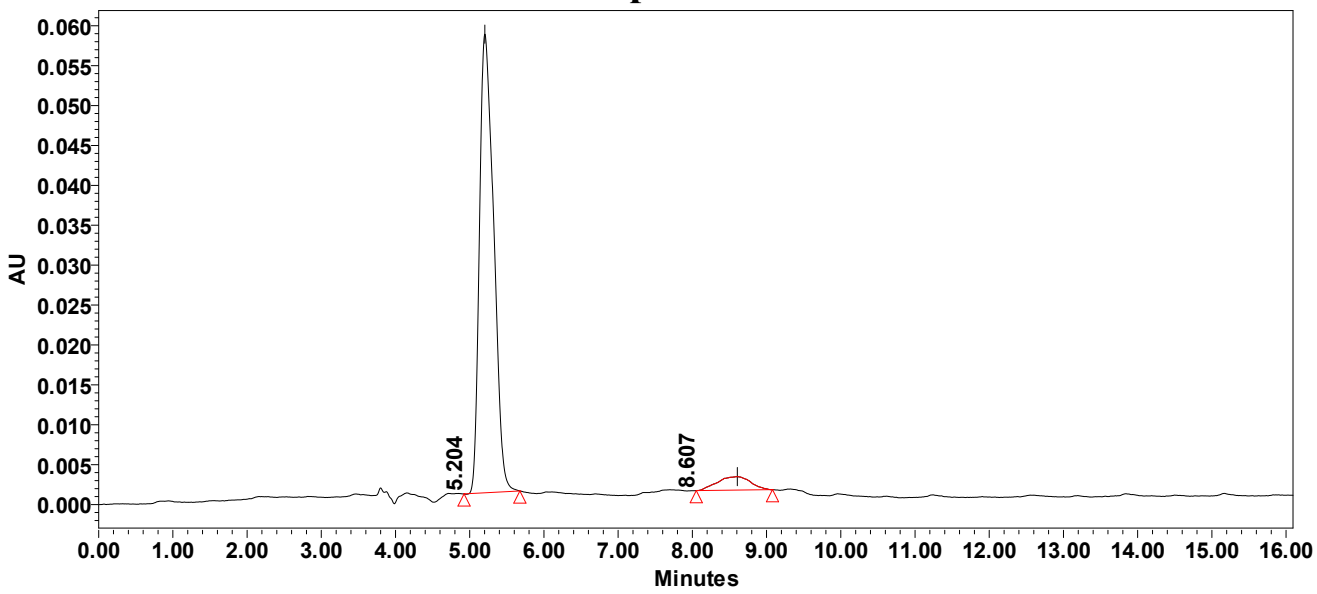

\begin{tabular}{cccc}
\hline Retention time & Height & Area & Area Percent (\%) \\
\hline 5.204 & 57493 & 767074 & 96.02 \\
8.586 & 1250 & 31803 & 3.98 \\
\hline
\end{tabular}

Compound 3. The flow rate was $1.0 \mathrm{~mL} / \mathrm{min}$ and detection at $383 \mathrm{~nm}$. The mobile phase was a mixture of methanol and $0.1 \%$ triethylamine aqueous solutions (17:3, $\mathrm{v} / \mathrm{v})$. 


\section{Compound 5}

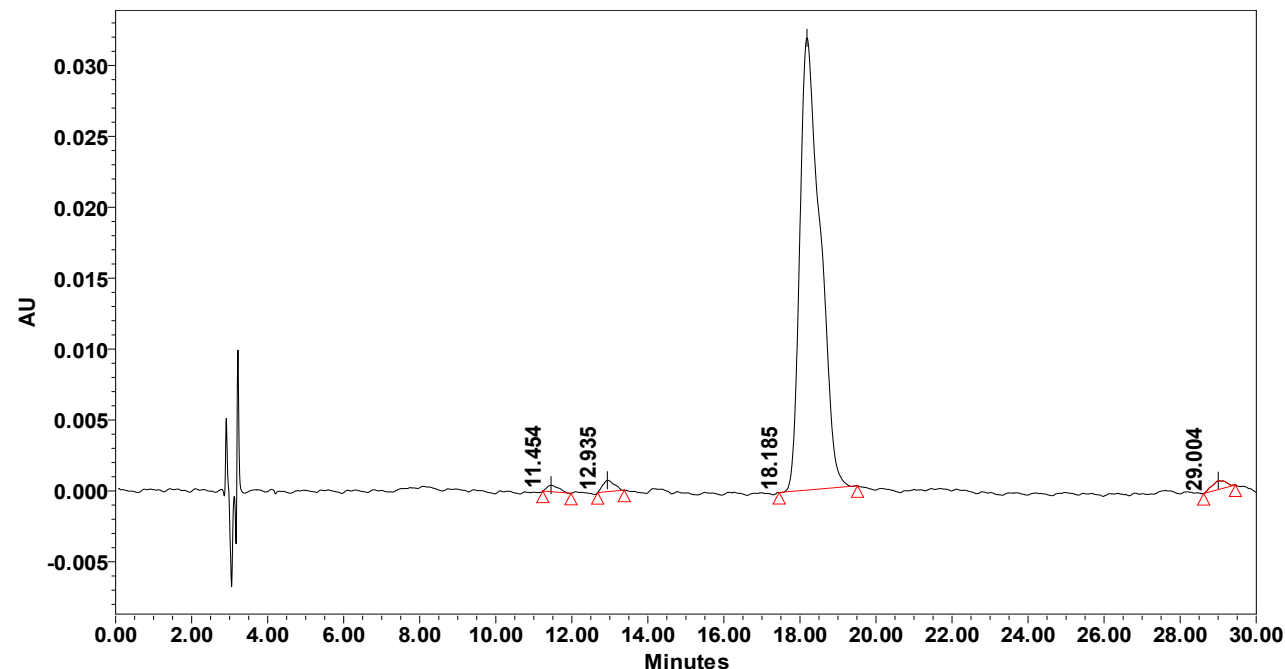

\begin{tabular}{cccc}
\hline Retention time & Height & Area & Area Percent $(\%)$ \\
\hline 11.454 & 461 & 10037 & 0.82 \\
12.935 & 805 & 16941 & 1.38 \\
18.185 & 31894 & 1185192 & 96.52 \\
29.004 & 624 & 15782 & 1.29 \\
\hline
\end{tabular}

Compound 5. The flow rate was $1.0 \mathrm{~mL} / \mathrm{min}$ and detection at $603 \mathrm{~nm}$. The mobile phase was a mixture of acetonitrile and ammonium acetate buffer $(50 \mathrm{mM})(17: 3$, $\mathrm{v} / \mathrm{v})$.

Prodrug AP-N=N-Cy

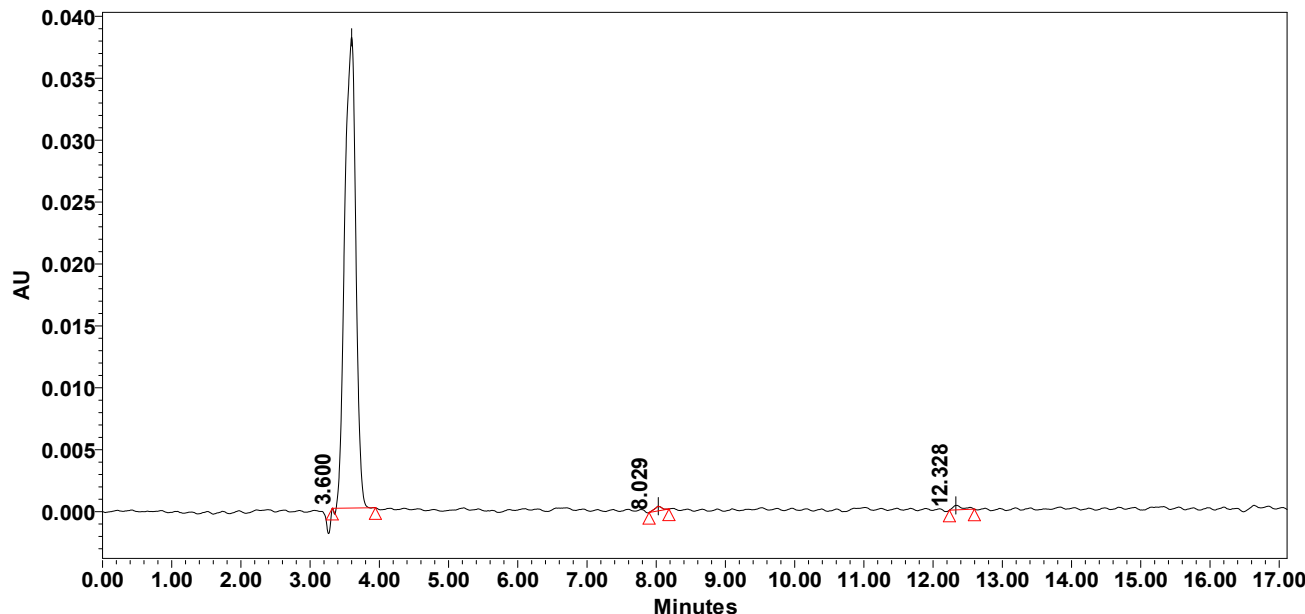

\begin{tabular}{cccc}
\hline Retention time & Height & Area & Area Percent $(\%)$ \\
\hline 3.600 & 38022 & 423795 & 98.53 \\
8.029 & 377 & 2674 & 0.62 \\
12.328 & 366 & 3650 & 0.85 \\
\hline
\end{tabular}

Prodrug AP-N=N-Cy. The flow rate was $1.0 \mathrm{~mL} / \mathrm{min}$ and detection at $603 \mathrm{~nm}$. The mobile phase was a mixture of methanol and $0.1 \%$ phosphoric acid aqueous solutions $(93: 7, \mathrm{v} / \mathrm{v})$. 


\section{References}

(1) Priewisch, B.; Rück-Braun, K. Efficient preparation of nitrosoarenes for the synthesis of azobenzenes. J. Org. Chem., 2005, 70(6), 2350-2352.

(2) Tsai, Y. H.; Essig, S.; James, J. R.; Lang, K.; Chin, J. W. Selective, rapid and optically switchable regulation of protein function in live mammalian cells. Nat. Chem., 2015, 7(7), 554-561.

(3) Samanta, A.; Vendrell, M.; Das, R.; Chang, Y. T. Development of photostable near-infrared cyanine dyes. Chem. Commun., 2010, 46(39), 7406-7408.

(4) Yuan, L.; Lin, W.; Zhao, S.; Gao, W.; Chen, B.; He, L.; Zhu, S. A unique approach to development of near-infrared fluorescent sensors for in vivo imaging. J. Am. Chem. Soc., 2012, 134(32), 13510-13523.

(5) Lee, K. H.; Beers, S. A.; Mori, M.; Wang, Z. Q.; Kuo, Y. H.; Li, L.; Liu S. Y.; Chang, J. Y.; Han, F. S.; Cheng, Y. C. Antitumor agents. 111. New 4-hydroxylated and 4-halogenated anilino derivatives of 4'-demethylepipodophyllotoxin as potent inhibitors of human DNA topoisomerase II. J. Med. Chem., 1990, 33(5), 1364-1368.

(6) Mickuviene, I.; Kirveliene, V.; Juodka, B. Experimental survey of non-clonogenic viability assays for adherent cells in vitro. Toxicol. In Vitro, 2004, 18, 639-648.

(7) Oomen, A. G.; Rompelberg, C. J M.; Bruil, M. A.; Dobbe, C. J.; Pereboom, G. D. P. K. H. ; Sips, A. J. A. M. Development of an in vitro digestion model for estimating the bioaccessibility of soil contaminants. Arch. Environ. Contam. Toxicol., 2003, 44, 0281-0287.

(8) Teruel, A. H.; Pérez-Esteve, É.; Gonzalez-Alvarez, I.; González-Álvarez, M.; Costero, A. M.; Ferri, D.; Parra, M.; Gaviña, P.; Merino, V.; Martínez-Mañez, R.; Sancenón, F. Smart gated magnetic silica mesoporous particles for targeted colon drug delivery: New approaches for inflammatory bowel diseases treatment. $J$. Control. Release, 2018, 281, 58-69. 